MEI

II, vol. 3

$\mathrm{n}^{0} 5$

\title{
La transparència informativa 2.0 en els portals de les administracions autonòmiques en 2012: una proposta de test d'avaluació
}

\author{
Romà Seguí i Francés \\ Institut Valencià de la Música. \\ Generalitat Valenciana.
}

\section{Recibido el 31-10-2012 \\ Aceptado en 18-12-2012}

\section{Resum}

La transparència informativa afecta als portals web de les administracions. L'objectiu és fer una proposta per avaluar-los, basant-se en tests realitzats per Transparencia Internacional España i Lluís Codina.

Paraules clau

Transparencia Internacional España; Lluís Codina; Avaluació de portals administratius; Portal administratiu; Test d'avaluació; Accés a la informació; Transparència informativa.

Transparency 2.0 portals regional governments in 2012: a proposed assessment test

Abstract

Information transparency affects government Webs. The goal is to make a proposal to evaluate, based on tests conducted by Transparencia Internacional España and Lluís Codina.

\section{Keywords}

Transparencia Internacional España; Lluís Codina; Government Portal evaluation; Government website; Evaluation test; Information access; Information transparency.

\section{Introducció}

La transparència informativa de les administracions és una assignatura pendent pel que fa a l'Estat espanyol. De tots els que formen la Unió Europea, n'és l'últim en escometre accions legislatives que regulen el dret a saber dels ciutadans; és a dir, excepció feta d'algunes comunitats com ara Galícia o les Illes, que van elaborar millor o pitjor les seues normes, el nostre Estat no havia escomés un plantejament legislatiu que permetera al ciutadà accedir a la informació que generen les administracions. El dret a saber, que s'ha conceptuat als darrers temps com a dret fonamental de la humanitat, és bàsic en els països democràtics.

L'aparició de la Llei 11/2007, d'accés electrònic dels ciutadans als Serveis Públics, implicà un primer pas per arribar a la Llei de Transparència. Com a mínim va servir per establir uns principis bàsics. Entre les finalitats de la norma (art. 3r), es poden trobar les següents:

4. Promover la proximidad con el ciudadano y la transparencia administrativa, así como la mejora continuada en la consecución del interés

SEGUÍ I FRANCÉS, ROMÀ. "La transparència informativa 2.0 en els portals de les administracions autonòmiques en 2012: una proposta de test d'avaluació". En: Métodos de información (MEI), II Época, Vol. 3, nº, 5, 2012, pp. 205-238.

DOI: http://dx.doi.org/10.5557/IIMEI3-N5-205238 
general.

6. Simplificar los procedimientos administrativos y proporcionar oportunidades de participación y mayor transparencia, con las debidas garantías legales.

Fins i tot, a l'article 4rt, on s'expliquen els principis generals, figurava:

b. Principio de igualdad con objeto de que en ningún caso el uso de medios electrónicos pueda implicar la existencia de restricciones o discriminaciones para los ciudadanos que se relacionen con las Administraciones Públicas por medios no electrónicos, tanto respecto al acceso a la prestación de servicios públicos como respecto a cualquier actuación o procedimiento administrativo sin perjuicio de las medidas dirigidas a incentivar la utilización de los medios electrónicos.

c. Principio de accesibilidad a la información y a los servicios por medios electrónicos en los términos establecidos por la normativa vigente en esta materia, a través de sistemas que permitan obtenerlos de manera segura y comprensible, garantizando especialmente la accesibilidad universal y el diseño para todos de los soportes, canales y entornos con objeto de que todas las personas puedan ejercer sus derechos en igualdad de condiciones, incorporando las características necesarias para garantizar la accesibilidad de aquellos colectivos que lo requieran.

i. Principio de neutralidad tecnológica y de adaptabilidad al progreso de las técnicas y sistemas de comunicaciones electrónicas garantizando la independencia en la elección de las alternativas tecnológicas por los ciudadanos y por las Administraciones Públicas, así como la libertad de desarrollar e implantar los avances tecnológicos en un ámbito de libre mercado. A estos efectos las Administraciones Públicas utilizarán estándares abiertos así como, en su caso y de forma complementaria, estándares que sean de uso generalizado por los ciudadanos.

És evident que la llei va significar un primer pas per aconseguir que les administracions assumiren el seu paper en la Societat de la Informació, acostant-se al ciutadà mitjançant les tecnologies. La norma, però, no deixava de ser una adaptació tecnològica de la Llei 30/1992, de Règim Jurídic de les Administracions i del Procediment Administratiu Comú, de tal manera que assumia antigues limitacions (Síndic de Greuges de Catalunya, 2012, p. 12-13). La Llei 11/2007, tot i significar un pas endavant, no reconeixia l'accés a la informació en un sentit ample. Calia considerar-la un repte per començar un camí que duguera al govern electrònic, fet que van anunciar els especialistes en la matèria (Cotino, Lorenzo; Valero, Julián, 2010). L'aposta per la Societat de la Informació no es pot resumir en permetre gestionar els tràmits administratius per Internet.

No obstant això, algunes organitzacions no governamentals, i en especial la branca espanyola de Transparència Internacional, havien encetat anàlisis sobre aquest tema en les diferents administracions espanyoles. Transparència Internacional (d'ara en avant TIE) ha elaborat uns qüestionaris que envia a ajuntaments, diputacions i administracions autonòmiques perquè els emplenen. Després publicita uns rànquings que han anat variant al llarg del temps. L'organització, a mesura que s'introdueixen nous preceptes legals, reelabora els qüestionaris per tal d'adaptar-los a l'actualitat. 
L'objectiu d'aquest treball és elaborar, a partir dels qüestionaris que TIE envia a les diferents comunitats autònomes, un test d'avaluació sobre transparència informativa en els webs d'aquestes administracions. El material que ofereix la organització, tot i ser molt valuós, oblida diferents aspectes que són essencials des de la nostra perspectiva professional, com ara l'accessibilitat o la incorporació de metadades. L'anàlisi de TIE aprofundeix en aspectes de caràcter administratiu i econòmic, incidint en problemes de contingut, i s'oblida del disseny que facilita a l'usuari accedir a la informació. Per això, s'ha emprat el qüestionari d'avaluació de Lluís Codina (2006) per arrodonir certs aspectes que quedaven desdibuixats. És evident que Codina fa una proposta que abasta en genèric els llocs webs, siga quin siga el seu contingut, però l'aplicació de bona part dels seus preceptes afavoreix un criteri que és essencial per entendre la transparència: un bon recurs digital està adreçat a recuperar de forma ràpida i eficaç els continguts que recull.

\section{Portal electrònic de l'administració: definicions i problemes}

Juan Carlos García Gómez (2001, p. 6) definia, de forma inicial, el portal com a: «un punto de entrada a internet donde se organizan sus contenidos, ayudando al usuario $y$ concentrando servicios y productos, de forma que le permitan realizar cuanto necesite hacer en la Red a diario, o al menos que pueda encontrar alli todo cuanto utiliza cotidianamente sin necesidad de salir de dicho sitio. El objetivo último [...] pretende ser su fidelización, es decir, conseguir que no lo usen de forma eventual sino que se habitúen a hacerlo a diario, lograr que vuelvan en repetidas ocasiones con expectativas de encontrar servicios que normalmente usan en internet, información interesante y que se establezca algún tipo de vínculo casi personal entre el usuario y el portal». És cert que un portal administratiu hauria de concentrar els serveis i productes per tal de facilitar al ciutadà la relació amb la institució que representa. Hauria de servir de porta d'entrada perquè aconseguira resoldre els problemes, dubtes i tràmits a què es veu exposat al llarg de la seua vida.

No obstant això, l'administració no pretén la fidelització perquè els seus usuaris són esclaus; és a dir, han de passar pel portal per realitzar determinades gestions, els agrade o no. Per exemple, la consulta d'un diari oficial o la sol-licitud d'una ajuda són activitats que qualsevol ciutadà pot dur a terme. La relació que es pot crear és diferent a la que es planteja a un portal que té uns productes que vol comercialitzar. El màrqueting podrà ser una eina eficient per guanyar una clientela determinada amb l'objectiu de fidelitzar-la. No és el cas de l'administració, en qualsevol de les seues formes. I aquest és un tema que cal incidir sempre, ja siga una administració autonòmica, un ajuntament o una diputació. El ciutadà acaba abocat als portals administratius per necessitat, no perquè els trie. Una altra cosa és que hi demane una gestió més eficaç, que és un objectiu que hauria de complir. A més a més, els portals administratius han de comptar amb un fet essencial: els ciutadans no solen entrar diàriament per solucionar gestions, cosa que obliga a emprar uns criteris bàsics per facilitar la seua consulta.

Juan Carlos García Gómez (2001, p. 6) afegia una segona definició en què afirmava que un portal és: «un conjunto de páginas estructuradas sobre la base de una organización de contenidos rigurosos y que éstas se componen de una o más páginas, pero sin que necesariamente esté implícita la idea de estructuración de información con criterios rigurosos». 
Potser aquesta s'adeqüe més a la realitat dels portals administratius, sobretot per la manca o l'excés d'estructuració rigorosa dels continguts. La visió que té part del personal de l'administració de la realitat ve categoritzada per tota una sèrie de normatives que dificulta la cerca d'informació. I no ens ha d'estranyar. Qui gestiona el carnet cultural per a persones jubilades, dependrà d'un departament diferent del que tramita ajudes per a estances en un balneari. Els dos procediments estan adreçats a persones jubilades. L'excés de rigor administratiu implicarà un coneixement previ del ciutadà per trobar-hi la informació, pel que fa als portals que només estan organitzats seguint els criteris orgànics.

Per tant, un portal administratiu serà aquell web que permeta al ciutadà trobar qualsevol informació que genere la pròpia administració, deixant de banda l'organització interna. El ciutadà podrà trobar allò que cerca mitjançant la centralització de l'oferta informativa i uns estàndards que homogeneïtzaran els continguts (Lorenzo Cotino, 2012, p. 33-34). L'estructura interna no ha de ser un problema, perquè cada administració té una organització diferent.

\section{Com es pot avaluar la transparència?}

\subsection{Limitacions prèvies}

Hem de partir de diferents espais per tal de comprendre l'abast de la transparència en els portals administratius:

- Estan subjectes a la normativa vigent pel que fa a disseny i continguts, de tal forma que cal resseguir els preceptes legals que són aplicables. D'una banda, s'han d'adaptar a la legislació que permet l'accessibilitat a col-lectius de discapacitats, aprofundint en els conceptes de igualtat de tots els ciutadans ${ }^{1}$. De l'altra, han de considerar que estan obligats a crear una infraestructura que facilite la relació electrònica entre el ciutadà i l'administració, alhora que han de publicitar per obligació certa informació que figura a la normativa. És a dir, tot i que siga de manera dispersa, la legislació pretén integrar els portals administratius en l'esfera del web 2.0. No es tracta ja d'oferir un tauler d'anuncis per tal de consultar-los. S'ha de passar a una concepció de l'administració en què el ciutadà es relaciona amb igualtat, imposant unes regles més flexibles²

- La normativa d'accés a la informació provoca molts entrebancs als gestors d'informació i documentació perquè les limitacions per accedir-hi en són moltes. La responsabilitat de garantir la legislació vigent pot passar per considerar-se una barrera excessiva. Cal afegir que també n'hi ha de gestors que gaudeixen de moure's entre preceptes legals per tal de no difondre el que conserven.

- El disseny dels portals administratius no sol fer-se de forma cooperativa amb tots els departaments de les entitats, generant-ne desequilibris que produeixen un silenci en les recerques. Moltes vegades la informació es troba als portals, però no s'hi ha descrit de forma adequada i cal ser un expert per aconseguir-hi el que es vol. L'excés de zel per traslladar la cultura impresa, la que figura als diaris oficials, a l'estructura d'Internet afavoreix la creació de laberints impracticables per al ciutadà, perquè els reglaments orgànics i funcionals no són 
fàcilment comprensibles i solen marcar l'estructura dels webs. Si afegim la moda de remodelar contínuament l'estructura de les administracions -per exemple, el Consell valencià modificà el nombre de conselleries quatre vegades entre $2009 \mathrm{i}$ 2011-, farem possible que el portal sempre estiga en obres. Per això, es molt important treballar en solucions que donen estabilitat, com ara fer una anàlisi de funcions i competències que agrupen en col-lectius o gran matèries els serveis que s'ofereixen per tal de suportar les derives polítiques. La confusió estructural, la que fa canviar tot de lloc en un tres i no res, és contrària a la transparència.

- Els criteris d'avaluació que proposa Lluís Codina (2006) són vàlids, però no contemplen la pràctica administrativa. És a dir, les relacions que s'estableixen en un portal administratiu van més enllà de les que categoritza. $\mathrm{O}$ dit d'altra manera, la majoria d'indicadors que proposa haurien d'estar assumits prèviament, perquè la informació que s'hi agavella és molt més complexa. La importància que ell dona a l'anàlisi del codi font, com a fita essencial per recuperar la informació, continua essent bàsica. Si se n'hagueren fet ressò, molt dels problemes que es generen haurien desaparegut. La manca de metadades és la millor solució per crear un silenci durador.

\subsection{Abast de la transparència}

La transparència afecta a diferents àmbits:

- Requereix d'una actitud en què l'administració facilite en qualsevol moment canals de comunicació perquè el ciutadà establisca una relació d'igualtat. L'administració no ha de ser un ens que tot ho sap i que només diu quan ho considera oportú. El ciutadà té dret a relacionar-se amb ella sense cap tipus de temor o prejudici. L'administració és de tots, i guanyarà més qualitat a mesura que entenga les necessitats i problemes dels ciutadans. El ciutadà, al remat, també ha de participar.

- La informació pot estar publicitada en els portals de forma tan complexa que només un col-lectiu d'experts puga entendre-la. La transparència ha de lluitar perquè els ciutadans puguen entendre allò que és menester saber. Una cosa és afegir un informe d'un centenar de planes redactat per especialistes, una altra publicar una llista resumida amb els indicadors més essencials.

- Les aplicacions han de comptar amb un disseny que permeta un accés fàcil i entenedor. No és només qüestió de plantejar uns indicadors que garantisquen l'existència de certes aplicacions o utilitats. Si un qüestionari és incomprensible, no serveix, perquè genera problemes. Si l'estructura jeràrquica de l'organització l'has de trobar amb esforç, tampoc no serveix.

- En el fons estem parlant del Dret a la informació com a element que s'ha d'integrar en la declaració de Drets humans. El ciutadà que viu en un Estat de Dret ha de poder preguntar a l'administració perquè, a banda de ser una forma de regular la seua activitat, és una pràctica que palesa esperit democràtic i participatiu. 
En resum, estem tematitzant tres àmbits que conflueixen de forma contínua:

a) La legalitat: els portals han de seguir una normativa vigent pel que fa a l'accessibilitat i a la informació que ha d'oferir al ciutadà. Les limitacions d'accés a la informació es presenten com a objectiu bàsic a resoldre en la futura Llei de Transparència. No obstant això, n'hi ha normes que obliguen a publicitar moltes dades, sobretot de caràcter econòmic i financer, que cal conèixer per analitzar els continguts dels portals administratius.

b) El disseny: no es tracta d'incorporar les dades sense més a un portal. És necessària una planificació que definisca els estàndards perquè tot siga recuperable. D'altra, s'ha d'entendre que l'accessibilitat, entesa des de qualsevol paràmetre, és bàsica perquè tothom aconseguisca la informació. A més de la quantitat, s'ha de pensar en la qualitat. Si els continguts no es troben fàcilment, el portal no és transparent.

c) Pensar en el ciutadà: les administracions parteixen d'un públic esclau, és a dir, d'un públic que s'ha d'adreçar a elles per tal de resoldre un problema. No ha cercar-ne cap d'usuari, perquè sempre en tindrà. La transformació d'aquesta visió és essencial per escometre una formulació de la transparència informativa. El ciutadà ha de ser l'element bàsic, com ho és en altre tipus de portal, en què la interacció entre l'usuari i el proveïdor de continguts és la que mena la forma de relacionar-se.

Seran aquests tres àmbits sobre els que es tractarà d'avaluar la transparència informativa, sobretot perquè és indispensable valorar aspectes que permetran o no que el ciutadà accedisca com cal a les seues peticions de documentació i informació.

\section{Accessibilitat, usabilitat i transparència informativa}

\subsection{Accesibilitat, limitacions lingüístiques i usuaris de les administracions}

És evident que la discapacitat no és patrimoni exclusiu de les persones que la pateixen amb un percentatge elevat. Qualsevol persona pot patir-ne una de temporal al llarg de la seua vida, ja siga perquè ha tingut un accident, ja siga una malaltia que no li ha permés desenvolupar les tasques que considerava habituals. A més a més, a mesura que les persones entren en la tercera edat les capacitats sensorials i intel-lectuals minven considerablement. Els portals administratius poden solucionar problemes que afecten a col-lectius amb limitacions visuals o auditives amb la implementació d'eines o serveis que facilitarien la comunicació. Hi ha iniciatives interessants com ara el Servizo de videointerpretación para persoas xordas ${ }^{3}$ de la Xunta de Galicia, en què un intèrpret rep les consultes que es fan al 012 i respon amb el llenguatge de signes, o l'aplicació per escoltar els textos de les disposicions del Boletín Oficial de Aragón $n^{4}$, en què tens la possibilitat de triar-ne les que vols per després escoltar-les. Aquestes iniciatives, però, són minoritàries.

No obstant això, el que és més preocupant és el que afecta a les discapacitats cognitives i a les limitacions lingüístiques i tecnològiques. D'una banda, un del entrebancs essencials dels portals administratius és el llenguatge que s'usa per explicar qualsevol servei o activitat. La translació de les normes al llenguatge comú 
no és pràctica habitual, però planteja problemes seriosos. Les disposicions legals tenen un llenguatge específic que cal conèixer per entendre quin és el seu abast. La translació a un llenguatge comú pot generar confusions. Això no vol dir que no es puga simplificar per tal que s'entenga millor. Pel que fa al llenguatge, no es pot argumentar que l'analfabetisme no és un problema real. A Espanya, segons la Encuesta de Població Activa ${ }^{5}$ del segon trimestre de 2012, n'hi ha més de 825.000 persones analfabetes. És evident que és un problema previ, perquè un nivell mínim d'alfabetització -en el sentit de saber llegir, escriure i realitzar operacions aritmètiques- és necessari per poder navegar en Internet ${ }^{6}$.

De l'altra, caldria definir quins són els usuaris potencials dels portals administratius. Una cosa és que pugues trobar-ne aplicacions adreçades a un públic especial, com ara xiquets, i una altra diferent, per exemple, que les tramitacions només les puguen gestionar persones físiques amb majoria d'edat o persones jurídiques, amb tots els requisits legals que cal. És a dir, s'ha de ser conscient de quins usuaris van a emprar el portal, de tal forma que caldria definir uns perfils per determinar els diferents nivells de llenguatge que s'haurien d'usar.

\subsection{Limitacions tecnològiques i accés a la informació}

Des que Gregg Vanderheiden (2000, p. 32-38) va afegir les limitacions tecnològiques com a element determinant de l'accessibilitat, l'objectiu de les anàlisis ha variat. L'article 4.i de la Llei 11/2007 d'accés electrònic dels ciutadans als Serveis Públics proposa el principi de neutralitat tecnològica:

garantizando la independencia en la elección de las alternativas tecnológicas por los ciudadanos y por las Administraciones Públicas, así como la libertad de desarrollar e implantar los avances tecnológicos en un ámbito de libre mercado. A estos efectos las Administraciones Públicas utilizarán estándares abiertos así como, en su caso y de forma complementaria, estándares que sean de uso generalizado por los ciudadanos.

Aquesta proposta normativa pot fonamentar l'intent d'acabar amb les limitacions tecnològiques, si entenem que els estàndards d'ús generalitzat permetran que els ciutadans aconseguisquen la informació que desitgen.

La realitat, però, és una altra. La Encuesta sobre equipamiento y uso de tecnologías de la información y comunicación en los hogares ${ }^{7}$ l'elabora el INE des de 2002. La darrera enquesta consultable és la de 2011. És interessant observar les dades que ofereix durant els darrers quatre anys perquè no s'ha incrementat l'ús dels portals administratius, cosa que implica un estancament que caldria avaluar-ne. Segons es pot observar al gràfic següent, l'evolució de l'ús d'Internet, pel que fa a la relació del ciutadà amb les administracions públiques, no ha augmentat considerablement, tot i que la fita que va suposar la Llei 11/2007. Si aquesta norma obligava a les diferents administracions a plantejar-se un accés efectiu als continguts i tramitacions que gestionen, no s'entén com les dades no són millors. 
Les tres preguntes són les següents:

- Cerca informació als webs de les administracions?

- S'hi descarrega formularis oficials?

- Els hi envia per Internet?

\section{Ús d'Internet a Espanya}

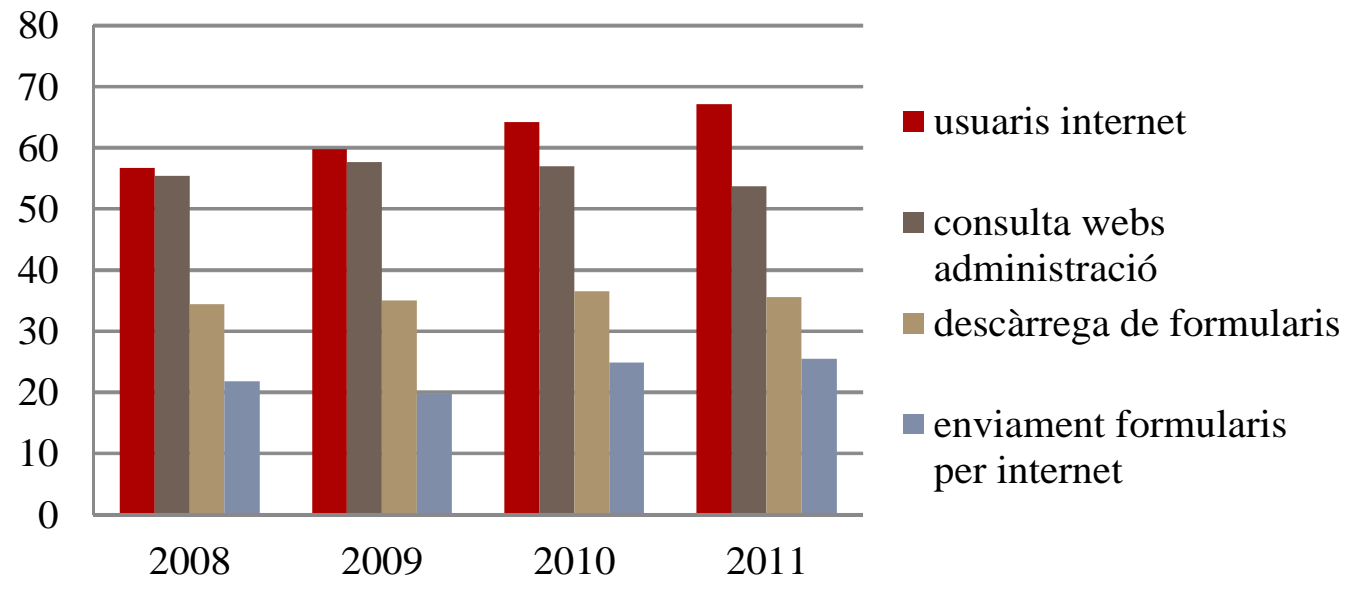

Figura 1.

Els resultats no són gens agraïts fins 2011. Segons el INE, havien obtingut informació de les pàgines web de les administracions el 55,4\% en 2008, el 57,7 \% en 2009, el $57 \%$ en $2010 \mathrm{i}$ el 53,7 en 2011. S'havien descarregat formularis oficials el $34,4 \%$ en 2008 , el $35 \%$ en 2009 , el $36,5 \%$ en 2010 i el $35,6 \%$ en 2011 . Els havien enviat emplenats per Internet el $21,8 \%$ en 2008 , el 19,8 \% en 2009 , el $24,9 \%$ en 2010 i el 25,5\% en 2011. Les dades de 2012 impliquen un increment: el 59,4\% havien obtingut informació de les pàgines web de les administracions, s'havien descarregat formularis oficials el $41 \%$ i els havien enviat emplenats per Internet 32,2 \%. Quines han estat les causes? És difícil saber-ho. Tanmateix, no impliquen un increment exagerat i evidencien que alguna cosa funciona malament. No ha estat un valor que ha anat pujant de forma continua.

El ciutadà fins 2011 ni havia incrementat la cerca d'informació als portals administratius ni la descàrrega de formularis. És a dir, l'aplicació de la Llei 11/2007 hauria d'haver significat un augment de consultes, perquè significava un acostament al ciutadà, sobretot en relació a les tramitacions. L'únic tret en què s'havia incrementat l'ús és en l'enviament de formularis per Internet, tot i que no fora de forma significativa. L'augment percentual de 2012 és notable, i és possible que responga a les expectatives que proposava la Llei $11 / 2007$, però evidencia de nou que no són valors que responen a una evolució.

També s'ha preguntat a les persones que no han emprat Internet per emplenar formularis quines han estat les causes. En 2011 el 12,7\% afirmava que no n'hi havia servei i en 2012 un 8,7\%; en 2011 el 6,1\% que havia tingut errors tècnics i en 2012 
un $5,2 \%$; el $21,1 \%$ que no tenia suficients habilitats i en 2012 un $21,7 \%$; en 2011 el $21,3 \%$ perquè els preocupava la seguretat de les dades personals i en 2012 el 17,3 \%; en 2011 el 25,7\% no tenia certificat electrònic i en 2012 el 25,1\%; en 2011 el $48 \%$ indicava per altres motius i en 2012 el 40,5 \%. És important advertir que la manca d'habilitats és un tema recurrent que afecta a la usabilitat, en tant que existeix la possibilitat d'haver definit formularis sense respectar-ne els principis mínims. D'altra, les dades sobre el fet de no tindre una certificació electrònica no varien gaire. Potser la resposta més significativa siga la de la no existència d'un servei, perquè implica que l'administració sí que està complint amb l'aplicació de la Llei 11/2007.

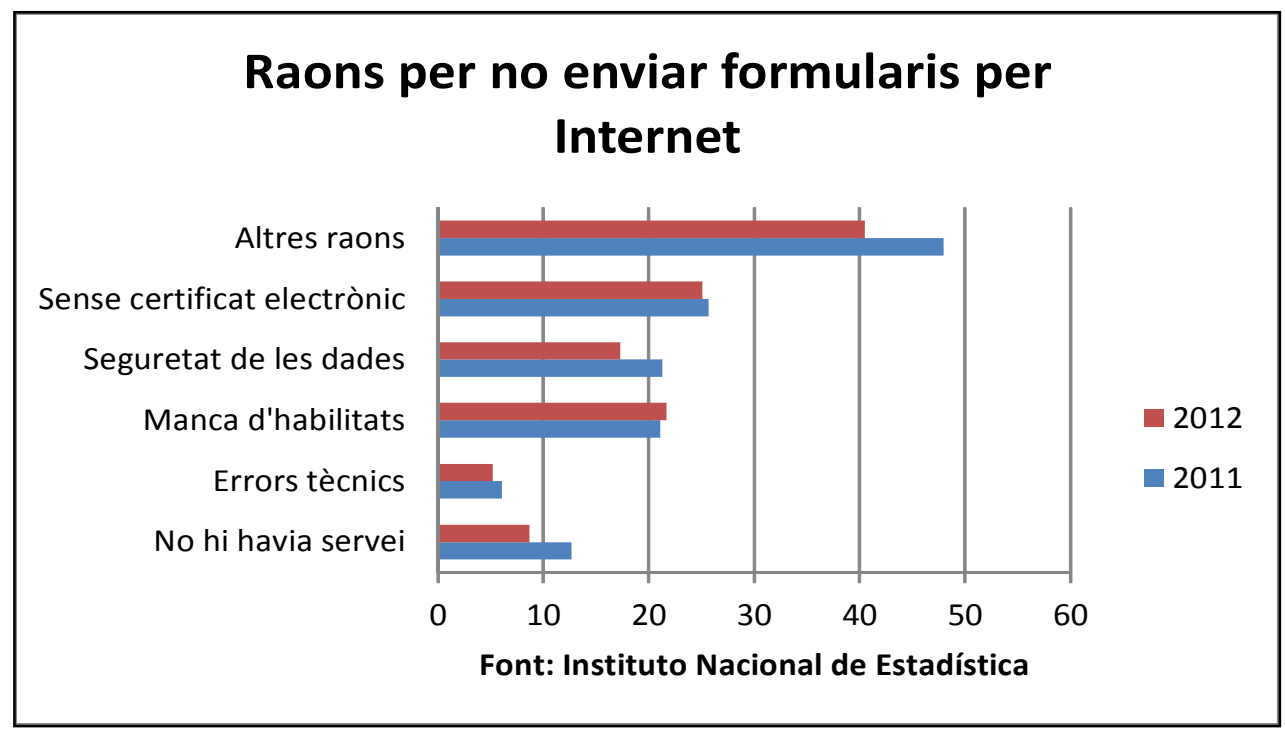

Figura 2

Aquestes dades contrasten amb les dades sobre l'ús freqüent d'Internet que proporciona Eurostat ${ }^{8}$. És a dir, si l'ús d'Internet s'ha incrementat constantment, perquè va disminuir l'ús pel que fa a comunicar-se amb l'administració fins a 2011? Per què el creixement no és continuat?

\begin{tabular}{|c|c|c|c|c|c|c|}
\hline 2005 & 2006 & 2007 & 2008 & 2009 & 2010 & 2011 \\
\hline 36 & 39 & 45 & 51 & 54 & 59 & 64 \\
\hline
\end{tabular}

Tabla 1

El Informe sobre el cumplimiento de los compromisos definidos en la Ley de acceso electrónico de los ciudadanos a los servicios públicos (2010) oferia unes dades espectaculars sobre l'adaptació de les diferents administracions a la norma, però les dades estadístiques fan pensar en una manca d'accessibilitat i usabilitat. És cert que al darrer any s'ha incrementat l'ús dels portals administratius, però no té sentit que els gràfics apunten a un creixement de l'ús d'Internet i no siga paral·lel pel que fa als portals de les administracions. 


\subsection{Transparència Internacional i el seu test d'avaluació}

Transparència Internacional (Transparency International) ${ }^{9}$ és una organització no governamental que es dedica a combatre la corrupció política arreu del món. Fou fundada en 1993 i està organitzada per capítols nacionals. El capítol espanyol començà a treballar en 2000. La seu social és la Fundació Ortega y Gasset-Marañón a Madrid.

Els índex de transparència que gestionen es basen en dos paràmetres essencials:

a) Formularis amb 80 indicadors que serveixen per conèixer-ne el grau assolit. Aquests estaven dividits en cinc grans àrees fins 2011, exceptuant el de la Gestió de l'Aigua, que en tenia 6. Les àrees responien als següents criteris:

- Informació sobre l'entitat

- Relacions amb el ciutadà i la societat

- Transparència econòmica-financera

- Transparència en la contractació de subministraments i serveis

- Transparència en matèries d'urbanisme i obres públiques

A partir de 2012 s'inclou un apartat específic sobre l'aplicació de la llei de Transparència. És evident que aquest darrer ha estat elaborat abans de tramitar -ne el text al Congrés dels Diputats, cosa que assenyala una projecció de preceptes que no sabem si en seran admesos i caldrà comprovar-ne quin articulat ha estat aprovat. Els formularis contenen una llista de 80 preguntes, amb la puntuació màxima que els organismes poden obtenir per cadascun dels apartats. Aquests figuren al web de l’organització amb antelació a la publicació dels resultats definitius, de manera que qualsevol ciutadà hi podrà conèixer quines són les preguntes que es faran. És molt important ressenyar que, des del començament, s'ha considerat el web el lloc on ha de trobar-se publicada la informació.

b) La recollida de dades. En principi TIE emplena els formularis amb una proposta de valoració - amb un manual en què s'explica la forma d'indicar les dades- i el remet a cadascuna de les administracions seleccionades. És a dir, una comissió d'analistes realitza un treball de camp previ, investigant-ne els llocs web per tal d'oferir una visió més acurada de la realitat. L’administració pot contestar amb una contra valoració que TIE haurà de valorar (per exemple, l'entitat ha publicat dades que no s'han trobat). En cas d'acceptar-ne la proposta, l'administració apareixerà amb la puntuació que TIE va assenyalar.

Fins a la data, TIE ha creat quatre índexs de transparència:

- Índex dels Ajuntaments (ITA). Les primeres dades es van recollir en 2008 d'un conjunt de les 100 majors corporacions locals de tot Espanya. En 2009, se n'amplià el nombre a 110 , dada que a hores d'ara continua.

- Índex de les Comunitats Autònomes (INCAU). Aquest en fa referència a 
l'executiu i legislatiu, provocant de vegades la confusió, perquè no es pot avaluar una cambra parlamentària amb els mateixos criteris que una administració autonòmica. Per ara, només ha aparegut el de 2010, tot i que s'està gestionant el de 2012.

- Índex de les Diputacions Provincials (INDIP). Només s'ha publicat el de 2012.

- Índex de la Gestió de l'Aigua (INTRAG). És el més complex de tots, perquè ha precisat d'un equip d'especialistes per tal de dur-lo endavant. L'àmbit d'anàlisi és el de les confederacions hidrogràfiques i les agències autonòmiques de l'aigua, deixant de banda les empreses municipals o supramunicipals que se n'encarreguen. S'han publicat els de 2010 i 2011.

De tot això, cal subratllar tres característiques essencials:

- TIE pretén aplicar la transparència 2.0 pel que fa a la utilització del web institucional com a lloc de referència per fer públiques les dades. Es tracta de ser transparent dins de l'àmbit d'Internet, cosa que implica una concepció actual de l'espai públic.

- Tot i que usa un esquema conceptual semblant, pel que fa a l'elaboració dels indicadors que han de valorar-se, n'especifica les diferències per a cadascun dels tipus d'administració que analitza. És a dir, separa les magnituds: estudia les administracions públiques segons un criteri de competència administrativa -que és d'agrair-perquè permet establir uns criteris més eficients.

- L'objectiu essencial que TIE persegueix és el dret a la informació del ciutadà. Per tant, els indicadors que farà servir anuncien un interès pels continguts en detriment d'aspectes que poden semblar formals, com ara l'accessibilitat, matèria pendent de l'organització. El dret a la informació és fonamental per fomentar una societat responsable i participativa, sobretot quan es tracta de palesar les actuacions dels governants amb fons públics.

Cal remarcar que moltes vegades TIE incorpora com a indicadors preceptes vigents, com ara la Llei 11/2007 d'accés electrònic, que haurien de contemplar-se als portals perquè són prescriptius. Una altra cosa és que no s'hi complisquen per comoditat o desconeixement.

\section{Proposta de test d'avaluació}

\subsection{Descripció}

La proposta que es fa es basa en indicadors que ha elaborat TIE, tot i que s'han adaptat a les necessitats dels portals de les administracions autonòmiques. Per exemple, alguns indicadors feien referència al poder legislatiu i s'han obviat per no considerar-los adequats. Se n'han introduït de nous, amb la intenció de no deixar de banda l'arquitectura, que passa un poc desapercebuda en els materials de TIE.

D'altra banda, els aspectes mediambientals no s'han recollit, sobretot perquè existeix un test d'aquestes característiques que realitza la Asociación de Ciencias Ambientales (2012), amb un nombre molt elevat d'indicadors. La seua inclusió 
haguera suposat un altre treball.

El test consta d'un número identificatiu per cada indicador, un títol, un apartat de preguntes que serveixen per emmarcar-lo, una breu explicació i la forma d'aplicar els valors. El nombre total d'indicadors és 73, uns quants menys que els que proposa TIE. Potser haguera estat més complet si s'hagueren afegit exemples, però l'extensió del treball haguera estat excessiva.

\subsection{Indicadors, puntuacions $i$ altres indicacions}

N'hi ha dos tipus d'indicadors: aquells que poden puntuar-se amb tres valors $(0,0.5 \mathrm{i}$ 1) i els que només en tenen dos ( $\begin{aligned} & 0 \\ & \text { i }\end{aligned}$ ). La diferència es basa en un tret essencial:

- Els que tenen tres valors poden matissar-se pel que fa a la consecució de l'objectiu, com ara incloure més dades en un directori. El o indica l'absència o la mala praxis. S'ha de considerar que la publicació exclusiva de les dades en els diaris oficials pot significar un valor 0 , perquè el ciutadà ha de trobar la informació relacionada amb els criteris o departaments que cerca. Per exemple, una relació de llocs de treball ha de figurar enllaçada al mateix departament. Que la legalitat exigisca que es publique al diari oficial, no implica un criteri de transparència. De la mateixa forma, tampoc no es pot considerar públic allò que només es pot accedir des de les intranets dels departaments. Aquestes pertanyen a l'esfera privada.

- Els que tenen dos valors no poden matissar-se. A la pregunta de si des de la pàgina d'acollida es pot arribar directament a les tramitacions només en calen dues respostes: sí o no. Per tant, són valors exclusius.

Per tal de ressaltar els indicadors que tenen alguna relació amb els que indica Lluís Codina, s'han ombrejats els requadres amb gris. En el cas de ser indicadors amb dos valors, s'han ombrejat amb roig.

S'ha afegit un annex en què es fa una correspondència entre els valors de Lluís Codina i alguns que es proposen, sobretot per aclarir dubtes que es plantejaran.

\section{Conclusions}

La cerca de la transparència informativa com a element essencial en la construcció d'una web de l'administració no és una qüestió de moda. Les administracions néixen amb l'objectiu de servir a la ciutadania, i no a l'inrevés. Aquest principi bàsic hauria de menar el tarannà dels polítics, sobretot pel que fa a afavorir-ne la transparència de la seua gestió. La transparència informativa s'ha de plantejar en l'àmbit del disseny del portal, perquè es permitisca l'accés al ciutadà, i en el dels continguts, perquè s'ha de palesar la gestió dels nostres polítics. Tots dos s'han de conjugar a la perfecció perquè se'n puga extreure la informació. L'elaboració d'un test d'avaluació serveix per definir uns paràmetres que s'haurien d'establir, per plantejar-nos que l'accés a la informació és un dret fonamental de l'individu, per repensar quina és la nostra professió.

És evident que caldria aplicar el test per tal de comprovar la seua utilitat. És una tasca que caldrà assumir-la en altre moment i d'una manera exclusiva. 


\section{Notas}

1. La legislació estatal que afecta a l'accessibilitat és la següent: Ley 34/2002, de 11 de julio, de servicios de la sociedad de la información y de comercio electrónico. Boletín Oficial del Estado, núm. 166 de 12 de julio de 2002; Ley 51/2003, de 2 de diciembre, de igualdad de oportunidades, no discriminación y accesibilidad universal de las personas con discapacidad. Boletín Oficial del Estado, núm. 289 de 3 de diciembre de 2003; Real Decreto 1494/2007, de 12 de noviembre, por el que se aprueba el Reglamento sobre las condiciones básicas para el acceso de las personas con discapacidad a las tecnologías, productos y servicios relacionados con la sociedad de la información y medios de comunicación social. Boletín Oficial del Estado, núm. 279 de 21 de noviembre de 2007.

2. La norma és la Ley 11/2007, de 22 de junio, de acceso electrónico de los ciudadanos a los Servicios Públicos. Boletín Oficial del Estado, núm. 150 de 23 de junio de 2007.

3. http://www.xunta.es/servizo-de-videointerpretacion-para-persoas-xordas

4. http://www.boa.aragon.es/EBOA/buscaEscuchar.html

5. http://www.ine.es/jaxi/menu.do?L=0\&type=pcaxis\&path=/t22/e308_mnu\&file=inebase

6. Lorenzo Cotino (2010b, p. 456-457) explica els drets que s'havien introduït a l'avant-projecte de la Llei 3/2010 d'Administració Electrònica de la Comunitat Valenciana i que no van ser aprovats. Entre ells es trobava el «Derecho a una acción pública de alfabetización digital que permita el ejercicio de los derechos de acceso electrónico a los servicios públicos y a los procedimientos administrativos, en condiciones de igualdad; así como al auxilio técnico y administrativo necesario para posibilitar tal acceso de modo eficaz y eficiente».

7. http://www.ine.es/jaxi/menu.do?type=pcaxis\&path=/t25/p450\&file=inebase

8. http://www.ine.es/jaxi/tabla.do?path=/t25/p450/e01/lo $/ \&$ file $=01001 . p x \& t y p e=p c a x i s \& L=0$

9. http://www.transparencia.org.es/

\section{Legislació bàsica}

Ley 34/2002, de 11 de julio, de servicios de la sociedad de la información y de comercio electrónico. Boletín Oficial del Estado, núm. 166 de 12 de julio de 2002.

Ley 51/2003, de 2 de diciembre, de igualdad de oportunidades, no discriminación y accesibilidad universal de las personas con discapacidad. Boletín Oficial del Estado, núm. 289 de 3 de diciembre de 2003.

Real Decreto 1494/2007, de 12 de noviembre, por el que se aprueba el Reglamento sobre las condiciones básicas para el acceso de las personas con discapacidad a las tecnologías, productos y servicios relacionados con la sociedad de la información y medios de comunicación social. Boletín Oficial del Estado, núm. 279 de 21 de noviembre de 2007.

Ley 30/1992, de 26 de noviembre, de Régimen Jurídico de las Administraciones Públicas y del Procedimiento Administrativo Común. Boletín Oficial del Estado, núm. 285 de 27 de noviembre de 1992.

Ley 11/2007, de 22 de junio, de acceso electrónico de los ciudadanos a los Servicios Públicos. Boletín Oficial del Estado, núm. 150 de 23 de junio de 2007.

Llei 3/2010, de 5 de maig, de la Generalitat, d'Administració Electrònica de la Comunitat Valenciana. Diari Oficial de la Comunitat Valenciana, núm. 6262 de 7 de maig de 2010. 
MEI, II, Vol. 3, n 5, pág. 218

\section{Bibliografia}

Asociación de Ciencias Ambientales (2012): $2^{\circ}$ Estudio sobre la calidad de la información ambiental autonómica en la red. Asociación de Ciencias Ambientales, Madrid.

Codina, Lluís (2006): Metodología de Análisis y Evaluación de Recursos Digitales en Línea. En: http://www.lluiscodina.com/metodos.htm [Consultat: 20.10.2012]

Cotino, Lorenzo; Valero, Julián (coord.) (2010): Administración electrónica: la Ley 11/2007, de 22 de junio, de acceso electrónico de los ciudadanos a los Servicios Públicos y los retos jurídicos del e-gobierno en España. Tirant lo Blanch, Valencia.

Cotino, Lorenzo (2010b): «Un futuro derecho a relacionarse informalmente con la Administración por medios electrónicos y la presente regulación del derecho a la carpeta ciudadana y a la autoadministración». Dins: Administración electrónica: la Ley 11/2007, de 22 de junio, de acceso electrónico de los ciudadanos a los Servicios Públicos y los retos jurídicos del e-gobierno en España. Tirant lo Blanch, Valencia, págs. 455-468.

Cotino, Lorenzo (2011): Libertades de expresión e información en Internet y las redes sociales: ejercicio, amenazas y garantías. PUV (Publicacions de la Universitat de València), València.

Cotino, Lorenzo (2012): «La regulación de la participación y de la transparencia a través de internet y medios electrónicos: propuestas concretas». P3T, Public Policies and Territory, vol. I, núm. 2, pág. 2739.

García Gómez, Juan Carlos (2001): «Portales de internet: concepto, tipología básica y desarrollo». El profesional de la información, vol. 10, núm 7-8, julio - agosto 2001, pág. 4-13.

Gobierno de España (2010): Informe sobre el cumplimiento de los compromisos definidos en la Ley de acceso electrónico de los ciudadanos a los servicios públicos. En: administracionelectronica.gob.es/recursos/ pae_020002444.pdf [Consultat: 20.10.2012]

Instituto Nacional de Estadística : Encuesta de población activa. En:

http://www.ine.es/jaxi/menu.do? L=0\&type=pcaxis\&path=/t22/e308_mnu\&file=inebase [Consultat: 20.10.2012]

Instituto Nacional de Estadística : Encuesta sobre equipamiento y uso de tecnologías de la información y comunicación en los hogares. En:

http://www.ine.es/jaxi/menu.do?type=pcaxis\&path=/t25/p450\&file=inebase [Consultat: 20.10.2012]

Instituto Nacional de Estadística: Nuevas tecnologías de la información y la comunicación. Datos Europeos. En:

http://www.ine.es/jaxi/tabla.do?path=/t25/p450/e0 1/10/\&file=01001.px\&type=pcaxis \&L=0

[Consultat: 20.10 .2012$]$

Síndic de Greuges de Catalunya (2012): Informe sobre el dret d'accés a la informació pública. Síndic de Greuges, Barcelona.

Transparencia Internacional: Transparencia Internacional. A: http://www.transparencia.org.es [Consultat: 20.10.2012]

Vanderheiden, Gregg (2000). «Fundamental Principles and Priority Setting for Universal Usability». En: Proceedings of Conference on Universal Usability (CUU) 2000. Association for Computing Machinery, p. 32-38. 
ANNEX I: PROPOSTA DE TEST D'AVALUACIÓ

\begin{tabular}{|c|c|c|c|c|c|}
\hline CODI & INDICADOR & OBSERVACIONS & \multicolumn{3}{|c|}{$\begin{array}{c}\text { PUNTUACIÓ } \\
\text { MÀXIMA }\end{array}$} \\
\hline \multirow[t]{2}{*}{1.} & $\begin{array}{l}\text { Informació } \\
\text { sobre } \\
\text { l'administració } \\
\text { autonòmica }\end{array}$ & & & & 23 \\
\hline & $\begin{array}{l}\text { Polítics i } \\
\text { personal } \\
\text { eventual }\end{array}$ & & & & 8 \\
\hline \multirow[t]{3}{*}{1.01.} & \multirow[t]{3}{*}{$\begin{array}{l}\text { Dades } \\
\text { biogràfiques }\end{array}$} & $\begin{array}{l}\text { Dades biogràfiques del president, consellers, } \\
\text { directors generals i càrrecs semblants en les } \\
\text { empreses públiques, entitats autònomes i } \\
\text { fundacions. }\end{array}$ & \multirow[t]{3}{*}{$\mathrm{O}$} & \multirow[t]{3}{*}{0,5} & \multirow[t]{3}{*}{1} \\
\hline & & $\begin{array}{l}\text { És important que no es deixe de banda la xarxa } \\
\text { d'empreses públiques, entitats autònomes i } \\
\text { fundacions -el que són ens instrumentals--, } \\
\text { perquè consumeixen una part important de } \\
\text { recursos. Acostuma a oblidar-se que pertanyen } \\
\text { a l'administració. }\end{array}$ & & & \\
\hline & & $\begin{array}{l}\text { En no aparèixer, o que figuren els organismes } \\
\text { sense els seus responsables, s'aplicarà un o; en } \\
\text { aparèixer només les dels responsables del } \\
\text { departaments que no són empreses públiques, } \\
\text { entitats autònomes, etc., s'aplicarà un o,5. En } \\
\text { complir tots els requisits, s'aplicarà un } 1 .\end{array}$ & & & \\
\hline \multirow[t]{3}{*}{1.02.} & \multirow[t]{3}{*}{$\begin{array}{l}\text { Comunicació } \\
\text { amb polítics }\end{array}$} & $\begin{array}{l}\text { Figuren les bústies electròniques i altres dades } \\
\text { que servisquen per contactar, com ara l'adreça } \\
\text { postal, el telèfon i fax? }\end{array}$ & \multirow[t]{3}{*}{0} & \multirow[t]{3}{*}{0,5} & \multirow[t]{3}{*}{ trat } \\
\hline & & $\begin{array}{l}\text { Que el ciutadà cerque la informació al web no } \\
\text { significa que no vulga relacionar-se d'altra } \\
\text { manera. És a dir, les dades dels fax, telèfon o } \\
\text { adreça postal són indispensables. }\end{array}$ & & & \\
\hline & & $\begin{array}{l}\text { En no aparèixer, s'aplicarà un } 0 \text {; en aparèixer de } \\
\text { forma incompleta les dades (bústia electrònica } \\
\text { però no adreça postal, per exemple), s'aplicarà } \\
\text { un } 0,5 \text {. En complir tots els requisits, s'aplicarà } \\
\text { un } 1 .\end{array}$ & & & \\
\hline \multirow[t]{3}{*}{1.03.} & \multirow[t]{3}{*}{$\begin{array}{l}\text { Registre d'alts } \\
\text { càrrecs }\end{array}$} & $\begin{array}{l}\text { Es fa públic el registre d'alts càrrecs? L'òrgan } \\
\text { encarregat de gestionar-ne les dades ho fa } \\
\text { públic? N'hi ha una llei d'incompatibilitats? }\end{array}$ & \multirow[t]{3}{*}{0} & \multirow[t]{3}{*}{0,5} & \multirow[t]{3}{*}{-} \\
\hline & & $\begin{array}{l}\text { No es tracta només de que existisca, i que } \\
\text { conste al web de l'administració. La informació } \\
\text { ha de ser consultable, ja siga en forma de base } \\
\text { de dades, ja siga com a llistat. }\end{array}$ & & & \\
\hline & & $\begin{array}{l}\text { Si les dades del registre no són consultables en } \\
\text { línia, s'aplicarà un } 0 \text {, fins i tot en el cas en què es } \\
\text { publiciten mitjançant la premsa, ja que la } \\
\text { utilitat del registre no és generar notícies. Si les } \\
\text { dades són consultables, però no s'afegeix la } \\
\text { normativa, s'aplicarà un } 0,5 . \text { Si les dades són } \\
\text { consultables i s'afegeix la normativa, s'aplicarà } \\
\text { un } 0,5 \text {. }\end{array}$ & & & \\
\hline
\end{tabular}


MEI, II, Vol. 3, nº 5, pág. 220

\begin{tabular}{|c|c|c|c|c|c|}
\hline \multirow[t]{3}{*}{1.04.} & \multirow[t]{3}{*}{$\begin{array}{l}\text { Agenda } \\
\text { d'activitats }\end{array}$} & $\begin{array}{l}\text { Es fan públiques les agendes d'activitats dels diferents } \\
\text { càrrecs polítics mitjançant una actualització com a } \\
\text { mínim diària? }\end{array}$ & \multirow[t]{3}{*}{$\mathbf{0}$} & \multirow[t]{3}{*}{0,5} & \multirow[t]{3}{*}{1} \\
\hline & & $\begin{array}{l}\text { L’agenda ha de conservar les dades anteriors a la data i } \\
\text { caldria que apareguera el programa d'activitats amb un dia } \\
\text { d'antelació. És evident que les agendes poden patir } \\
\text { modificacions per greus imprevistos, però només per això. } \\
\text { L'agenda del president i dels consellers ha de ser pública. }\end{array}$ & & & \\
\hline & & $\begin{array}{l}\text { De no existir l'agenda, o de no preveure les activitats amb un } \\
\text { dia d'antelació, s'aplicarà un O. Si només està visible la del } \\
\text { president, s'aplicarà un } 0,5 \text {. En complir tots els requisits, } \\
\text { s'aplicarà un } 1 .\end{array}$ & & & \\
\hline \multirow[t]{3}{*}{1.05 . } & \multirow[t]{3}{*}{ Assessors } & $\begin{array}{l}\text { Es fa públic el nombre total de persones que ocupen llocs de } \\
\text { personal eventual? Se'n fan relacions detallades, amb el nom } \\
\text { i cognoms, per cadascun dels departaments? Se’n coneix el } \\
\text { sou, separant els diferents complements? Se'n fa un estudi } \\
\text { comparatiu de l'evolució? N'hi ha de personal contractat per } \\
\text { assessorar que no figure com a eventual? }\end{array}$ & \multirow[t]{3}{*}{$\mathrm{O}$} & \multirow[t]{3}{*}{0,5} & \multirow[t]{3}{*}{1} \\
\hline & & $\begin{array}{l}\text { És molt important separar el personal nomenat com a } \\
\text { eventual del que compleix les mateixes funcions amb altre } \\
\text { tipus de contractació. D'altra banda, n'hi ha dues formes } \\
\text { d'encarar la publicitat: amb llistes detallades amb els criteris } \\
\text { especificats o amb llistes en què figura el nombre } \\
\text { d'eventuals, la xifra total del sou, etc. A més a més s'ha de } \\
\text { comprovar que estan incorporats al directori de cada } \\
\text { departament. No es pot puntuar si només apareixen les } \\
\text { dades al diari oficial. }\end{array}$ & & & \\
\hline & & $\begin{array}{l}\text { Si no apareix cap llista, s'aplicarà un } 0 . \text { Si n'hi ha una en què } \\
\text { les dades són genèriques, s'aplicarà un } 0,5 \text {. En el cas de } \\
\text { complir tots els requisits, s'aplicarà un } 1 .\end{array}$ & & & \\
\hline \multirow[t]{3}{*}{1.06.} & \multirow[t]{3}{*}{$\begin{array}{l}\text { Sous dels } \\
\text { alts càrrecs }\end{array}$} & $\begin{array}{l}\text { Es fan públics els sous dels alts càrrecs de l'administració i } \\
\text { dels ens instrumentals? }\end{array}$ & \multirow[t]{3}{*}{ O } & \multirow[t]{3}{*}{0,5} & \multirow[t]{3}{*}{1} \\
\hline & & Han de figurar desglossats. & & & \\
\hline & & $\begin{array}{l}\text { Si no són consultables, s'aplicarà un } 0 . \text { En el cas de només } \\
\text { figurar els que ocupen càrrecs a l'administració autonòmica, } \\
\text { obviant els dels que dirigeixen empreses públiques, } \\
\text { fundacions, etc., o a l'inrevés, s'aplicarà un } 0,5 \text {. En el cas de } \\
\text { complir tots els requisits, s'aplicarà un } 1 .\end{array}$ & & & \\
\hline \multirow[t]{3}{*}{1.07.} & \multirow[t]{3}{*}{$\begin{array}{l}\text { Indemnitzaci } \\
\text { ons }\end{array}$} & $\begin{array}{l}\text { Es fan públiques les possibles indemnitzacions que poden } \\
\text { rebre els càrrecs per acabament de la seua activitat? }\end{array}$ & \multirow[t]{3}{*}{ O } & \multirow[t]{3}{*}{0,5} & \multirow[t]{3}{*}{1} \\
\hline & & $\begin{array}{l}\text { Ha de figurar una llista en què es publicite la tipologia de } \\
\text { càrrecs, detallant-ne l'import. Els dels ens instrumentals han } \\
\text { de considerar-se a banda. }\end{array}$ & & & \\
\hline & & $\begin{array}{l}\text { Si no hi ha cap llista, s'aplicarà un } 0 . \text { En el cas de ser } \\
\text { incompleta, s'aplicarà un } 0,5 \text {. En el cas de complir tots els } \\
\text { requisits, s'aplicarà un } 1 .\end{array}$ & & & \\
\hline \multirow[t]{3}{*}{1.08.} & \multirow{3}{*}{$\begin{array}{l}\text { Perfils en } \\
\text { xarxes } \\
\text { socials }\end{array}$} & $\begin{array}{l}\text { Els alts càrrecs tenen perfils en les xarxes socials per rebre } \\
\text { qualsevol tipus de suggeriment? }\end{array}$ & \multirow[t]{3}{*}{0} & \multirow[t]{3}{*}{0,5} & \multirow[t]{3}{*}{1} \\
\hline & & $\begin{array}{l}\text { És un exercici de transparència mantindre un perfil en les } \\
\text { xarxes socials que permeta el diàleg amb els ciutadans. }\end{array}$ & & & \\
\hline & & $\begin{array}{l}\text { En el cas de no tindre'n cap o de tindre'n un que no permeta } \\
\text { afegir comentaris dels ciutadans, s'aplicarà un o. En el cas de } \\
\text { tindre'n un que no s'actualitza setmanalment, s'aplicarà un } \\
\text { O,5. En el cas d'actualitzar-lo amb una freqüència inferior a } \\
\text { la setmanal, s'aplicarà un } 1 \text {. }\end{array}$ & & & \\
\hline
\end{tabular}


MEI, II, Vol. 3, nº 5, pág. 221

\begin{tabular}{|c|c|c|c|c|c|}
\hline \multicolumn{4}{|c|}{ Organització } & \multicolumn{2}{|c|}{5} \\
\hline \multirow[t]{3}{*}{1.09 . } & \multirow[t]{3}{*}{$\begin{array}{l}\text { Funcions dels } \\
\text { diferents } \\
\text { departaments }\end{array}$} & $\begin{array}{l}\text { S'especifiquen les funcions dels diferents } \\
\text { departaments de l'administració, ja sia de caràcter } \\
\text { públic o privat, informant-ne de les seues funcions? }\end{array}$ & \multirow[t]{3}{*}{$\mathrm{O}$} & \multirow[t]{3}{*}{0,5} & \multirow[t]{3}{*}{1} \\
\hline & & $\begin{array}{l}\text { Tot i que la legislació és important, cal incidir en } \\
\text { què el ciutadà no és lector habitual dels textos } \\
\text { normatius, com ara els reglaments orgànics i } \\
\text { funcionals, cosa que implica que se n'ha d'eliminar } \\
\text { aquesta limitació amb redaccions més adequades } \\
\text { per al ciutadà. }\end{array}$ & & & \\
\hline & & $\begin{array}{l}\text { Si no figuren de forma explícita, s'aplicarà un } \mathrm{O} . \mathrm{Si} \\
\text { només reprodueixen els textos legals, s'aplicarà un } \\
\mathrm{O}, 5 . \text { Si s'ha elaborat un text més senzill i aclaridor, } \\
\text { afegint els textos legals, s'aplicarà un } 1 .\end{array}$ & & & \\
\hline \multirow{3}{*}{\multicolumn{2}{|c|}{ 1.10. Mapa web }} & $\begin{array}{l}\text { El portal té un mapa web on figure de forma } \\
\text { actualitzada i jerarquitzada l'estructura orgànica? }\end{array}$ & \multirow[t]{3}{*}{$\mathrm{O}$} & & \multirow[t]{3}{*}{1} \\
\hline & & $\begin{array}{l}\text { Els canvis constants d'estructura orgànica en els } \\
\text { governs complica l'actualització de les dades en els } \\
\text { portals. A més a més, confon al ciutadà, obligant-lo } \\
\text { a perdre temps. }\end{array}$ & & & \\
\hline & & $\begin{array}{l}\text { Aquest valor es exclusiu. Si no en té de mapa, O. Si } \\
\text { en té, } 1 .\end{array}$ & & & \\
\hline \multirow[t]{3}{*}{1.11} & \multirow[t]{3}{*}{$\begin{array}{l}\text { Navegació per } \\
\text { criteri de } \\
\text { dependència } \\
\text { departamental }\end{array}$} & $\begin{array}{l}\text { La dependència administrativa es manté com a } \\
\text { criteri de navegació? La conselleria té una relació } \\
\text { exhaustiva dels departaments que depenen, fins i } \\
\text { tot les entitats, amb uns enllaços diferenciats? És } \\
\text { fàcil realitzar una navegació de l'organisme } \\
\text { superior a l'inferior i a l'inrevés? }\end{array}$ & \multirow[t]{3}{*}{$\mathrm{O}$} & & \multirow[t]{3}{*}{1} \\
\hline & & $\begin{array}{l}\text { Els ens instrumentals -les empreses públiques, } \\
\text { entitats autònomes, fundacions, etc.-- han de } \\
\text { figurar dins de l'organigrama de l'administració, } \\
\text { palesant la seua dependència administrativa. }\end{array}$ & & & \\
\hline & & $\begin{array}{l}\text { Aquest valor es exclusiu. Si no en fa ús de la } \\
\text { dependència administrativa com a criteri de } \\
\text { navegació, } \mathrm{O} . \mathrm{Si} \text { en fa, } 1 .\end{array}$ & & & \\
\hline \multirow{3}{*}{\multicolumn{2}{|c|}{$\begin{array}{l}\text { Adequació de } 1 \\
\text { funcions als } \\
\text { departaments }\end{array}$}} & $\begin{array}{l}\text { Les funcions figuren a cada departament? És a dir, } \\
\text { les funcions dels òrgans inferiors figuren al seu } \\
\text { apartat, separades de les que són comunes a tot el } \\
\text { departament? }\end{array}$ & \multirow[t]{3}{*}{$\mathrm{O}$} & \multirow[t]{3}{*}{0,5} & \multirow[t]{3}{*}{1} \\
\hline & & $\begin{array}{l}\text { De vegades, les funcions només apareixen en les } \\
\text { pàgines del departament superior i no apareixen } \\
\text { desglossades en els inferiors, de tal forma que el } \\
\text { ciutadà no sap qui n'és el responsable. }\end{array}$ & & & \\
\hline & & $\begin{array}{l}\text { De no aparèixer a l'òrgan inferior, s'aplicarà un } 0 . \\
\text { Si només reprodueixen els textos legals, s'aplicarà } \\
\text { un } 0,5 . \text { Si s'ha elaborat un text més senzill i } \\
\text { aclaridor, afegint els textos legals, s'aplicarà un } 1 .\end{array}$ & & & \\
\hline \multirow{2}{*}{\multicolumn{2}{|c|}{ 1.13. Orientació }} & $\begin{array}{l}\text { S'indica a la part superior la ruta que s'està } \\
\text { seguint? }\end{array}$ & \multirow[t]{2}{*}{$\mathrm{O}$} & & \multirow[t]{2}{*}{1} \\
\hline & & $\begin{array}{l}\text { Sense indicacions d'aquest tipus el ciutadà es pot } \\
\text { perdre o pot confondre la informació que cerca. }\end{array}$ & & & \\
\hline
\end{tabular}


MEI, II, Vol. 3, nº 5, pág. 222

\begin{tabular}{|c|c|c|c|c|}
\hline \multicolumn{4}{|c|}{ Personal funcionarial i laboral } & \multirow{4}{*}{$\begin{array}{c}5 \\
1\end{array}$} \\
\hline \multirow[t]{3}{*}{1.14.} & \multirow[t]{3}{*}{$\begin{array}{l}\text { Relacions de llocs de } \\
\text { treball de } \\
\text { l'administració }\end{array}$} & $\begin{array}{l}\text { Es publiquen les relacions completes de llocs de } \\
\text { treball dels diferents departaments de } \\
\text { l'administració? }\end{array}$ & \multirow[t]{3}{*}{0} & \\
\hline & & $\begin{array}{l}\text { És a dir, les relacions dels diferents departaments que } \\
\text { conformen l'administració. Han de figurar amb la } \\
\text { informació del departament. El ciutadà no té de } \\
\text { cercar-les al diari oficial. }\end{array}$ & & \\
\hline & & $\begin{array}{l}\text { Aquest valor és exclusiu. Si no en fa de publicitat, } 0 . \\
\text { Si en fa, } 1 .\end{array}$ & & \\
\hline \multirow[t]{3}{*}{1.15 . } & \multirow[t]{3}{*}{$\begin{array}{l}\text { Relacions de llocs de } \\
\text { treball dels ens } \\
\text { instrumentals }\end{array}$} & $\begin{array}{l}\text { Es publiquen les relacions completes de llocs de } \\
\text { treball de les diferents empreses, fundacions i ens } \\
\text { instrumentals de l'administració? }\end{array}$ & \multirow[t]{3}{*}{0} & \multirow[t]{3}{*}{1} \\
\hline & & $\begin{array}{l}\text { És a dir, de les empreses, entitats autònomes, } \\
\text { fundacions (allò que s'anomena ens instrumentals) de } \\
\text { l'administració. Han de figurar amb la informació del } \\
\text { departament. El ciutadà no té de cercar-les al diari } \\
\text { oficial. }\end{array}$ & & \\
\hline & & $\begin{array}{l}\text { Aquest valor és exclusiu. Si no en fa de publicitat, } 0 \text {. } \\
\text { Si en fa, } 1 .\end{array}$ & & \\
\hline \multirow[t]{3}{*}{1.16.} & \multirow[t]{3}{*}{$\begin{array}{l}\text { Publicitat de l'Oferta } \\
\text { Pública d'Ocupació }\end{array}$} & $\begin{array}{l}\text { Es publica l'Oferta Pública d'Ocupació amb el seu } \\
\text { desplegament reglamentari? }\end{array}$ & \multirow[t]{3}{*}{ O } & \multirow[t]{3}{*}{1} \\
\hline & & $\begin{array}{l}\text { És a dir, l'OPO, les convocatòries, composició dels } \\
\text { tribunals, actes d'avaluació, resolucions, etc. El } \\
\text { ciutadà no té de cercar-les al diari oficial. }\end{array}$ & & \\
\hline & & $\begin{array}{l}\text { Aquest valor és exclusiu. Si no en fa de publicitat, } 0 \text {. } \\
\text { Si en fa, } 1 \text {. }\end{array}$ & & \\
\hline \multirow[t]{3}{*}{1.17.} & \multirow{3}{*}{$\begin{array}{l}\text { Publicitat dels } \\
\text { concursos de } \\
\text { personal }\end{array}$} & $\begin{array}{l}\text { Es publiquen els concursos de personal amb el seu } \\
\text { desplegament reglamentari? }\end{array}$ & \multirow[t]{3}{*}{0} & \multirow[t]{3}{*}{1} \\
\hline & & $\begin{array}{l}\text { És a dir, les convocatòries, composició dels tribunals, } \\
\text { actes d'avaluació, resolucions, etc. }\end{array}$ & & \\
\hline & & $\begin{array}{l}\text { Aquest valor és exclusiu. Si no en fa de publicitat, } 0 \text {. } \\
\text { Si en fa, } 1 .\end{array}$ & & \\
\hline \multirow[t]{3}{*}{1.18.} & \multirow{3}{*}{$\begin{array}{l}\text { Comunicació de la } \\
\text { informació que afecta } \\
\text { a l'Oferta Pública } \\
\text { d'Ocupació }\end{array}$} & $\begin{array}{l}\text { Existeixen mecanismes d'alerta perquè qualsevol } \\
\text { ciutadà puga accedir-hi? }\end{array}$ & \multirow[t]{3}{*}{ O } & \multirow[t]{3}{*}{1} \\
\hline & & $\begin{array}{l}\text { És important que l'administració difonga mitjançant } \\
\text { qualsevol canal qualsevol convocatòria (RSS, xarxes } \\
\text { socials, butlletins electrònics, etc.) }\end{array}$ & & \\
\hline & & $\begin{array}{l}\text { Aquest valor és exclusiu. Si no en fa de publicitat, } 0 \text {. } \\
\text { Si en fa, } 1 .\end{array}$ & & \\
\hline \multicolumn{3}{|c|}{ Patrimoni } & & 2 \\
\hline \multirow[t]{3}{*}{1.19.} & \multirow[t]{3}{*}{ Llista d'immobles } & $\begin{array}{l}\text { Es fa pública la llista d'immobles propis, o en règim } \\
\text { d'arrendament, que ocupa l'administració? }\end{array}$ & \multirow[t]{3}{*}{0} & \multirow[t]{3}{*}{1} \\
\hline & & $\begin{array}{l}\text { No serveix que es publiquen les disposicions al diari } \\
\text { oficial sobre afectacions, desafectacions patrimonials, } \\
\text { etc. Ha de ser una llista en que figuren els immobles } \\
\text { amb indicacions sobre la propietat o el règim } \\
\text { d'arrendament, adreça postal, adscripció al } \\
\text { departament i import anual de l'arrendament. }\end{array}$ & & \\
\hline & & $\begin{array}{l}\text { Aquest valor es exclusiu. En el cas de no publicitar- } \\
\text { se, s'aplicarà un } 0 . \text { En cas afirmatiu, un } 1 .\end{array}$ & & \\
\hline \multirow[t]{3}{*}{1.20.} & \multirow{3}{*}{$\begin{array}{l}\text { Llista de vehicles } \\
\text { oficials }\end{array}$} & Es fa pública la llista de vehicles oficials? & \multirow[t]{3}{*}{0} & \multirow[t]{3}{*}{1} \\
\hline & & $\begin{array}{l}\text { S'entén que abastaria tota la flota, adscrivint-los als } \\
\text { departaments. }\end{array}$ & & \\
\hline & & $\begin{array}{l}\text { Aquest valor es exclusiu. En el cas de no publicitar- } \\
\text { se, s'aplicarà un } 0 . \text { En cas afirmatiu, un } 1 .\end{array}$ & & \\
\hline
\end{tabular}


MEI, II, Vol. 3, nº 5, pág. 223

\begin{tabular}{|c|c|c|c|c|}
\hline \multicolumn{3}{|c|}{ Normes } & & 3 \\
\hline \multirow[t]{3}{*}{1.21} & \multirow[t]{3}{*}{$\begin{array}{l}\text { Publicitat dels } \\
\text { avant-projectes } \\
\text { de llei }\end{array}$} & $\begin{array}{l}\text { Es publiquen els avant-projectes de llei perquè } \\
\text { puguen ser consultats, amb l'objectiu de rebre } \\
\text { propostes de modificació? }\end{array}$ & \multirow[t]{3}{*}{0} & 1 \\
\hline & & $\begin{array}{l}\text { No es tracta de què s'envien els textos per correu a } \\
\text { les entitats que es consideren més adequades per } \\
\text { comentar les disposicions. L'objectiu és que } \\
\text { qualsevol ciutadà puga consultar-los i comentar-los. }\end{array}$ & & \\
\hline & & $\begin{array}{l}\text { Aquest valor es exclusiu. En el cas de no publicitar- } \\
\text { se amb la possibilitat de rebre esmenes, s'aplicarà un } \\
\text { o. En cas afirmatiu, un } 1 .\end{array}$ & & \\
\hline \multirow[t]{3}{*}{1.22.} & \multirow[t]{3}{*}{$\begin{array}{l}\text { Publicitat dels } \\
\text { reglaments }\end{array}$} & $\begin{array}{l}\text { Es publiquen els projectes de reglaments perquè } \\
\text { puguen ser consultats, amb l'objectiu de rebre } \\
\text { propostes de modificació? }\end{array}$ & \multirow[t]{3}{*}{$\mathrm{O}$} & \multirow[t]{3}{*}{1} \\
\hline & & $\begin{array}{l}\text { No es tracta de què s'envien els textos per correu a } \\
\text { les entitats que es consideren més adequades per } \\
\text { comentar les disposicions. L'objectiu és que } \\
\text { qualsevol ciutadà puga consultar-los i comentar-los. }\end{array}$ & & \\
\hline & & $\begin{array}{l}\text { Aquest valor es exclusiu. En el cas de no publicitar- } \\
\text { se amb la possibilitat de rebre esmenes, s'aplicarà un } \\
\text { o. En cas afirmatiu, un } 1 .\end{array}$ & & \\
\hline \multirow[t]{3}{*}{1.23.} & \multirow{3}{*}{$\begin{array}{l}\text { Publicitat dels } \\
\text { acords del } \\
\text { Consell }\end{array}$} & Es fan públics els acords sencers del Consell? & \multirow[t]{3}{*}{$\mathrm{O}$} & \multirow[t]{3}{*}{1} \\
\hline & & $\begin{array}{l}\text { No es tracta de publicitar notes de premsa que } \\
\text { resumeixen els acords presos en les reunions de } \\
\text { Consell. Es tracta de mostrar-los sencers. }\end{array}$ & & \\
\hline & & $\begin{array}{l}\text { Aquest valor es exclusiu. En el cas de no publicitar- } \\
\text { se, s'aplicarà un } 0 . \text { En cas afirmatiu, un } 1 .\end{array}$ & & \\
\hline 2. & $\begin{array}{l}\text { Relacions amb } \\
\text { els ciutadans i la } \\
\text { societat }\end{array}$ & & & 21 \\
\hline
\end{tabular}


MEI, II, Vol. 3, nº 5, pág. 224

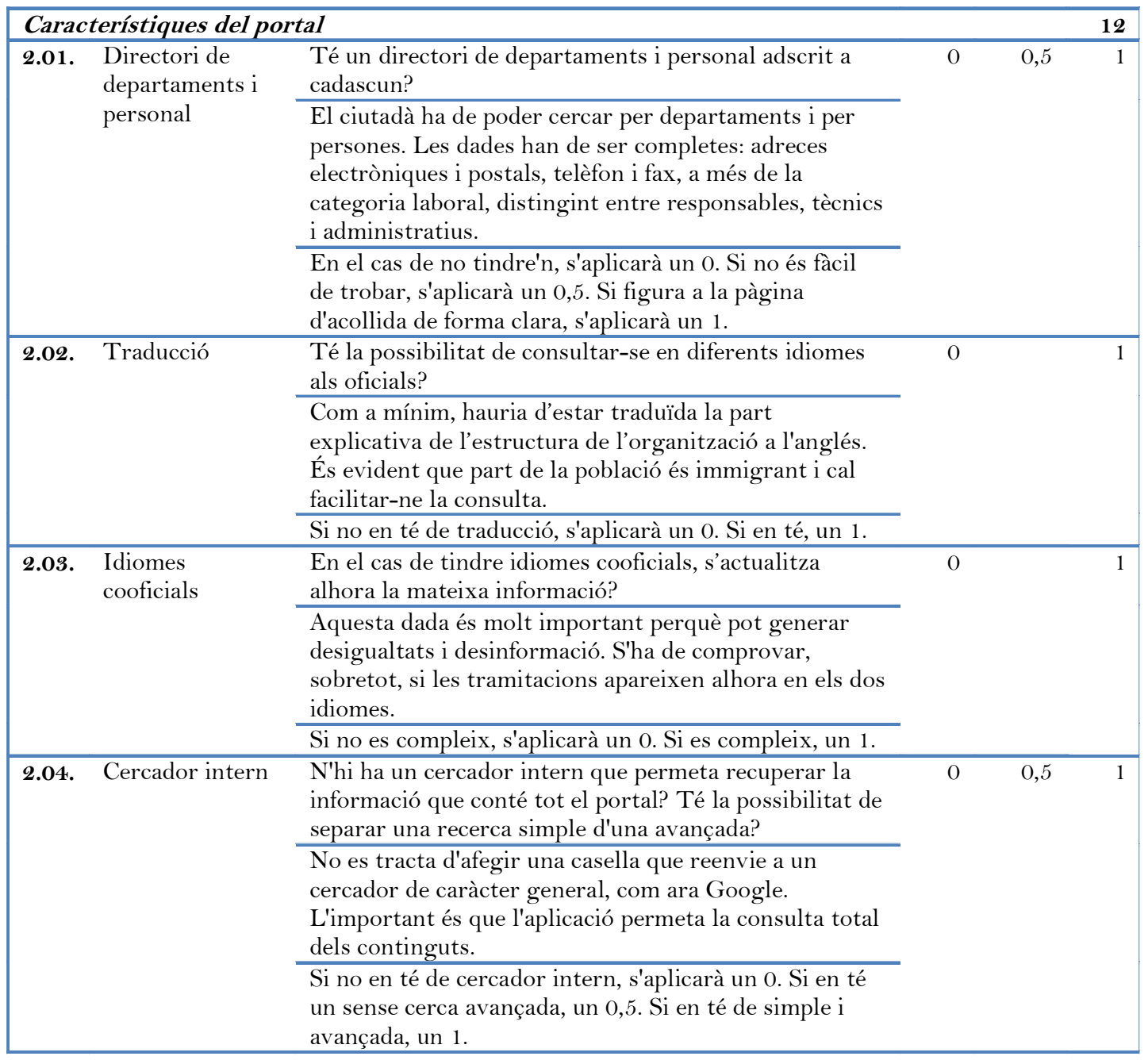


MEI, II, Vol. 3, nº 5, pág. 225

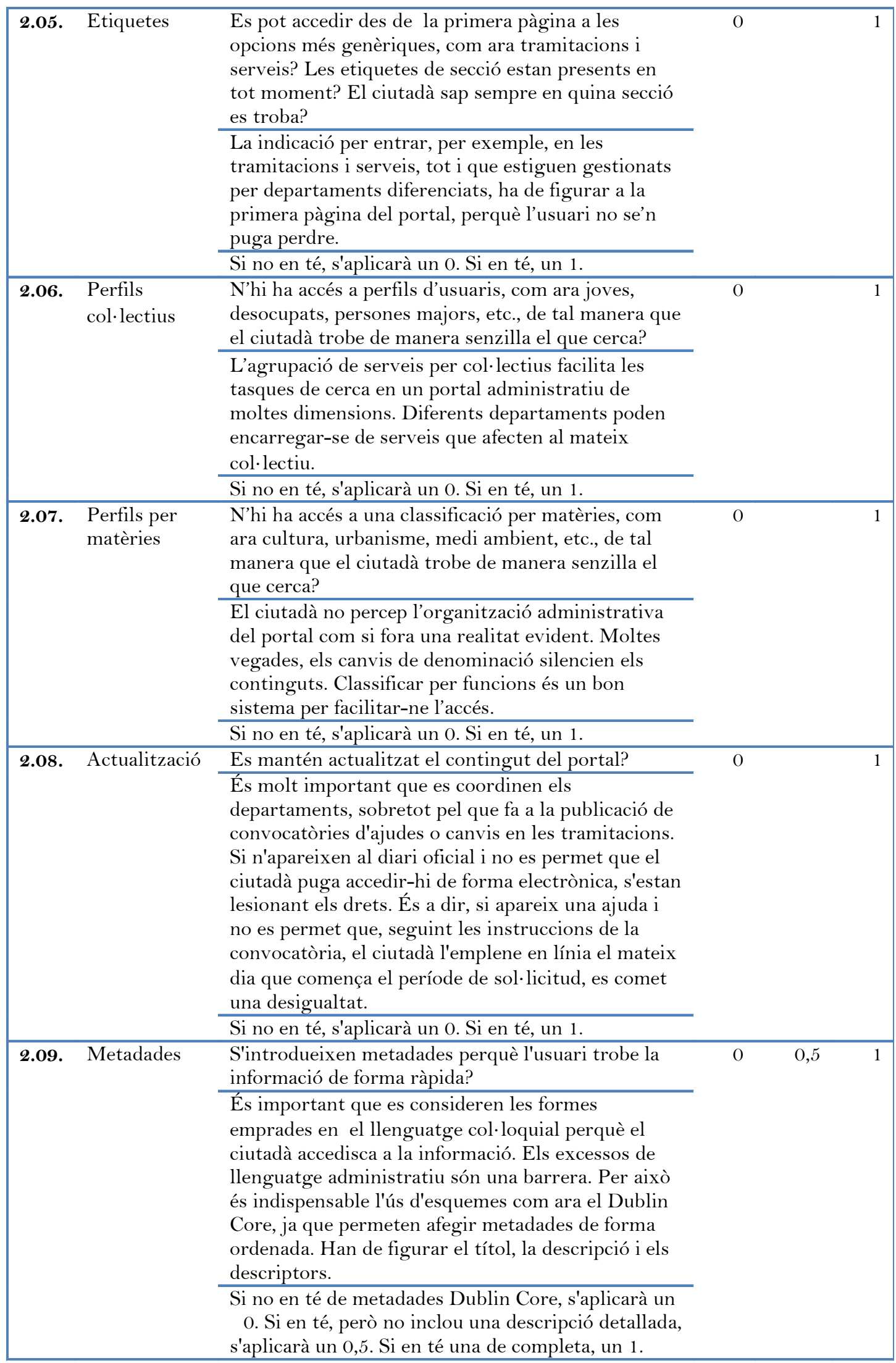


MEI, II, Vol. 3, nº 5, pág. 226

\begin{tabular}{|c|c|c|c|c|c|}
\hline \multirow[t]{3}{*}{2.10 . } & \multirow[t]{3}{*}{ Accessibilitat } & $\begin{array}{l}\text { Compleix amb els estàndards d'accessibilitat de } \\
\text { doble AA de la W3C? }\end{array}$ & \multirow[t]{3}{*}{$\mathbf{O}$} & & \multirow[t]{3}{*}{1} \\
\hline & & $\begin{array}{l}\text { La legislació espanyola demana una doble AA } \\
\text { per als portals de les administracions públiques. }\end{array}$ & & & \\
\hline & & $\begin{array}{l}\text { Aquest valor és doble: si té la certificació de } \\
\text { W3Consortium de AA, un } 1 . \text { Si no en té, un o. }\end{array}$ & & & \\
\hline \multirow[t]{3}{*}{2.11 . } & \multirow[t]{3}{*}{$\begin{array}{l}\text { Xarxes socials i } \\
\text { difusió }\end{array}$} & $\begin{array}{l}\text { S'usen les xarxes socials per publicitar les } \\
\text { activitats dels departaments? }\end{array}$ & \multirow[t]{3}{*}{$\mathrm{O}$} & \multirow[t]{3}{*}{0,5} & \multirow[t]{3}{*}{1} \\
\hline & & $\begin{array}{l}\text { Les xarxes socials figuren com a canals } \\
\text { d'informació essencials pel que fa a la difusió } \\
\text { d'informació en segments importants de la } \\
\text { població. }\end{array}$ & & & \\
\hline & & $\begin{array}{l}\text { Si no en fan ús, s'aplicarà un } \mathrm{O} \text {. Si no en fan ús } \\
\text { de forma sistemàtica, un } 0,5 \text {. Si en fan sempre, } \\
\text { un } 1 \text {. }\end{array}$ & & & \\
\hline \multirow[t]{3}{*}{2.12.} & \multirow[t]{3}{*}{$\begin{array}{l}\text { Manual } \\
\text { corporatiu de } \\
\text { disseny }\end{array}$} & $\begin{array}{l}\text { S'ha pensat en homogeneïtzar la presentació de } \\
\text { tot el portal? S'han tingut en compte la } \\
\text { presentació dels textos perquè puguen llegir-se } \\
\text { fàcilment? }\end{array}$ & \multirow[t]{3}{*}{$\mathrm{O}$} & & \multirow[t]{3}{*}{1} \\
\hline & & $\begin{array}{l}\text { El manual corporatiu de disseny ha de permetre } \\
\text { una homogeneïtat que faça reconèixer la } \\
\text { totalitat d'un portal amb un estil de publicació } \\
\text { eficaç. }\end{array}$ & & & \\
\hline & & Si no en té, s'aplicarà un $\mathrm{O}$. Si en té, un 1. & & & \\
\hline
\end{tabular}


MEI, II, Vol. 3, nº 5, pág. 227

\begin{tabular}{|c|c|c|c|c|c|}
\hline \multicolumn{3}{|c|}{ Informació i atenció al ciutadà } & & & 5 \\
\hline \multirow[t]{3}{*}{2.13 . } & \multirow[t]{3}{*}{$\begin{array}{l}\text { Catàleg de } \\
\text { serveis }\end{array}$} & $\begin{array}{l}\text { N'hi ha un catàleg de serveis que abrace tant els que són } \\
\text { en línia com els que no, indicant horaris d'atenció al } \\
\text { públic, taxes, etc.? }\end{array}$ & \multirow[t]{3}{*}{0} & \multirow[t]{3}{*}{0,5} & \multirow[t]{3}{*}{1} \\
\hline & & $\begin{array}{l}\text { Una cosa són les tramitacions que es realitzen en línia i } \\
\text { altra els serveis presencials, com ara la visita a un } \\
\text { centres d'atenció primària o a les biblioteques públiques. } \\
\text { És important que figure tota la informació: taxes per } \\
\text { expedir un carnet, horaris, etc. }\end{array}$ & & & \\
\hline & & $\begin{array}{l}\text { Si no en té, s'aplicarà un } 0 . \text { Si en té un d'incomplet, } \\
\text { s'aplicarà un } 0,5 . \text { En el cas de publicitar-ho tot, un } 1 .\end{array}$ & & & \\
\hline \multirow[t]{3}{*}{2.14 . } & \multirow[t]{3}{*}{$\begin{array}{l}\text { Tramitacions } \\
\text { en línia }\end{array}$} & $\begin{array}{l}\text { La majoria de les tramitacions pot realitzar-se en línia? } \\
\text { Es poden descarregar els formularis? Les interfícies són } \\
\text { fàcils o complexes? }\end{array}$ & \multirow[t]{3}{*}{0} & \multirow[t]{3}{*}{0,5} & \multirow[t]{3}{*}{1} \\
\hline & & $\begin{array}{l}\text { La forma adequada és permetre que es faça la tramitació } \\
\text { sencera en línia i alhora que qualsevol puga } \\
\text { descarregar-se els formularis per entregar-los en les } \\
\text { oficines. A més a més, les interfícies han de contemplar } \\
\text { els requisits mínims: missatges d'error entenedors, } \\
\text { ajudes senzilles, formularis fàcils d'emplenar, etc. }\end{array}$ & & & \\
\hline & & $\begin{array}{l}\text { Si no en té, s'aplicarà un } 0 . \text { Si només en té un } 50 \% \text { que } \\
\text { es puga realitzar la gestió sencera, un o,5. En el cas de } \\
\text { superar el } 70 \% \text { un } 1 .\end{array}$ & & & \\
\hline \multirow[t]{3}{*}{2.15 . } & \multirow[t]{3}{*}{$\begin{array}{l}\text { Indicadors } \\
\text { sobre el } \\
\text { sistema sanitari } \\
\text { públic i el } \\
\text { privat que està } \\
\text { finançat }\end{array}$} & $\begin{array}{l}\text { Es publiquen amb periodicitat el nombre de centres } \\
\text { sanitaris, la ratio habitant/llit hospitalari i les llistes } \\
\text { d'espera? Figuren les inversions públiques en el sistema } \\
\text { privat, indicant també les mateixes dades que en el } \\
\text { públic? }\end{array}$ & \multirow[t]{3}{*}{$\mathrm{O}$} & & \multirow[t]{3}{*}{1} \\
\hline & & $\begin{array}{l}\text { El ciutadà ha de conèixer el funcionament del sistema } \\
\text { sanitari públic amb informació periòdica. Les dades han } \\
\text { d'estar contrastades amb altres fonts diferents a les que } \\
\text { proporciona la comunitat autònoma: Euroestat és una } \\
\text { bona font d'informació. }\end{array}$ & & & \\
\hline & & $\begin{array}{l}\text { Si es fan públiques les dades periòdicament, un 1. En } \\
\text { cas contrari, un } 0 .\end{array}$ & & & \\
\hline \multirow[t]{3}{*}{2.16 . } & \multirow[t]{3}{*}{$\begin{array}{l}\text { Indicadors } \\
\text { sobre el } \\
\text { sistema } \\
\text { educatiu públic } \\
\text { i concertat }\end{array}$} & $\begin{array}{l}\text { Es publiquen amb periodicitat el nombre de centres } \\
\text { educatius, la ratio alumne/professor i alumne/aula, els } \\
\text { serveis de transport o menjador escolar? També figuren } \\
\text { les inversions públiques en centres concertats, indicant } \\
\text { les mateixes dades que en el sistema públic? }\end{array}$ & \multirow[t]{3}{*}{0} & & \multirow[t]{3}{*}{1} \\
\hline & & $\begin{array}{l}\text { El ciutadà ha de conèixer el funcionament del sistema } \\
\text { d'ensenyament públic amb informació. Les dades han } \\
\text { d'estar contrastades amb altres fonts diferents a les que } \\
\text { proporciona la comunitat autònoma: Euroestat és una } \\
\text { bona font d'informació. }\end{array}$ & & & \\
\hline & & $\begin{array}{l}\text { Si es fan públiques les dades periòdicament, un 1. En } \\
\text { cas contrari, un } 0 .\end{array}$ & & & \\
\hline \multirow[t]{3}{*}{2.17 . } & \multirow[t]{3}{*}{$\begin{array}{l}\text { Bústia de } \\
\text { correu genèrica }\end{array}$} & $\begin{array}{l}\text { N'hi ha aplicacions que permeten al ciutadà adreçar } \\
\text { sol·licituds d'informació a qualsevol organisme de } \\
\text { l'administració? }\end{array}$ & \multirow[t]{3}{*}{$\mathrm{O}$} & & \multirow[t]{3}{*}{1} \\
\hline & & $\begin{array}{l}\text { Caldria diferenciar entre les bústies que haurien } \\
\text { d'aparèixer en qualsevol pàgina que oferira un servei i } \\
\text { una mena de finestra única que reenviara les sol·licituds } \\
\text { als diferents departaments. Aquesta darrera hauria de } \\
\text { figurar a la pàgina inicial del portal. }\end{array}$ & & & \\
\hline & & Si en té, un 1 . En cas contrari, un 0. & & & \\
\hline
\end{tabular}


MEI, II, Vol. 3, nº 5, pág. 228

\begin{tabular}{|c|c|c|c|c|}
\hline \multicolumn{4}{|c|}{ Grau de compromís amb els ciutadans } & \multirow{4}{*}{$\begin{array}{c}4 \\
1\end{array}$} \\
\hline \multirow[t]{3}{*}{2.18.} & \multirow[t]{3}{*}{$\begin{array}{l}\text { Normativa sobre } \\
\text { participació ciutadana }\end{array}$} & $\begin{array}{l}\text { Es fa pública la normativa sobre la transparència } \\
\text { informativa, les formes de participació ciutadana o } \\
\text { els codis de bon govern? }\end{array}$ & \multirow[t]{3}{*}{$\mathrm{O}$} & \\
\hline & & $\begin{array}{l}\text { La normativa ha de ser la de caràcter estatal i } \\
\text { autonòmic. }\end{array}$ & & \\
\hline & & Si se'n fa pública, un 1. En cas contrari, un 0. & & \\
\hline \multirow[t]{3}{*}{2.19.} & \multirow[t]{3}{*}{ Cartes de serveis } & Es publiquen les cartes de serveis? & \multirow[t]{3}{*}{$\mathrm{O}$} & \multirow[t]{3}{*}{1} \\
\hline & & $\begin{array}{l}\text { És important que figuren enllaçades amb el } \\
\text { servei. No es tracta només de que es publiquen al } \\
\text { diari oficial. }\end{array}$ & & \\
\hline & & Si se'n fan públiques, un 1. En cas contrari, un 0. & & \\
\hline \multirow[t]{3}{*}{ 2.20. } & \multirow[t]{3}{*}{$\begin{array}{l}\text { Consells de } \\
\text { participació }\end{array}$} & $\begin{array}{l}\text { Es fan públiques les actes íntegres dels consells de } \\
\text { participació ciutadana? }\end{array}$ & \multirow[t]{3}{*}{$\mathrm{O}$} & \multirow[t]{3}{*}{1} \\
\hline & & $\begin{array}{l}\text { Els consells de participació ciutadana són els } \\
\text { òrgans col·legiats en què té representació la } \\
\text { societat mitjançant associacions, col·lectius } \\
\text { professionals, etc. }\end{array}$ & & \\
\hline & & Si se'n fan públiques, un 1. En cas contrari, un 0. & & \\
\hline \multirow[t]{3}{*}{2.21.} & \multirow{3}{*}{$\begin{array}{l}\text { Informes de les } \\
\text { sindicatures i } \\
\text { seguiment de } \\
\text { compliment }\end{array}$} & $\begin{array}{l}\text { Es publiquen els informes de les sindicatures de } \\
\text { greuges i de comptes? }\end{array}$ & \multirow[t]{3}{*}{$\mathrm{O}$} & \multirow[t]{3}{*}{1} \\
\hline & & $\begin{array}{l}\text { Els informes s'han d'editar perquè siguen } \\
\text { consultables de forma fàcil, amb un sumari extens } \\
\text { i amb enllaços als capítols o paràgrafs. }\end{array}$ & & \\
\hline & & Si se'n fan públics, un 1. En cas contrari, un 0. & & \\
\hline & \multicolumn{2}{|c|}{ Transparència en la contractació } & & 14 \\
\hline \multicolumn{4}{|c|}{ Informació genèrica sobre la contractació } & 4 \\
\hline \multirow[t]{3}{*}{3.01.} & \multirow[t]{3}{*}{$\begin{array}{l}\text { Publicitat meses de } \\
\text { contractació }\end{array}$} & $\begin{array}{l}\text { Es fa pública la informació sobre les meses de } \\
\text { contractació de serveis (forma de designació, } \\
\text { composició, actes, etc.)? }\end{array}$ & \multirow[t]{3}{*}{$\mathrm{O}$} & \multirow[t]{3}{*}{1} \\
\hline & & $\begin{array}{l}\text { Els procediments de contractació són els més } \\
\text { cridaners pel que fa al tema de la possible } \\
\text { corrupció. La legislació estipula procediments } \\
\text { molt clars. }\end{array}$ & & \\
\hline & & Si se'n fa pública, un 1. En cas contrari, o. & & \\
\hline \multirow[t]{3}{*}{ 3.02. } & \multirow[t]{3}{*}{$\begin{array}{l}\text { Publicitat resolucions } \\
\text { d'adjudicació }\end{array}$} & $\begin{array}{l}\text { Es fan públiques les resolucions d'adjudicació, } \\
\text { detallant l'objecte del contracte, partida } \\
\text { pressupostària, import, tipus de publicitat, nom } \\
\text { del licitador i nombre de licitadors que han } \\
\text { concursat? }\end{array}$ & \multirow[t]{3}{*}{$\mathrm{O}$} & \multirow[t]{3}{*}{1} \\
\hline & & La legislació estipula procediments molt clars. & & \\
\hline & & Si se'n fa públiques, un 1. En cas contrari, un o. & & \\
\hline \multirow[t]{3}{*}{ 3.03. } & \multirow{3}{*}{$\begin{array}{l}\text { Publicitat de les } \\
\text { modificacions de } \\
\text { contractes }\end{array}$} & $\begin{array}{l}\text { Es fan públiques les modificacions dels contractes } \\
\text { formalitzats? }\end{array}$ & \multirow[t]{3}{*}{$\mathrm{O}$} & \multirow[t]{3}{*}{1} \\
\hline & & La legislació estipula procediments molt clars. & & \\
\hline & & Si se'n fa públiques, un 1. En cas contrari, un $O$. & & \\
\hline \multirow[t]{3}{*}{ 3.04. } & \multirow[t]{3}{*}{$\begin{array}{l}\text { Publicitat sobre dades } \\
\text { estadístiques }\end{array}$} & $\begin{array}{l}\text { Es fan públiques dades estadístiques sobre els } \\
\text { percentatges en volum pressupostari dels } \\
\text { contractes adjudicats, separant-ne les diferents } \\
\text { modalitats que contempla la legislació? }\end{array}$ & $\mathrm{O}$ & 1 \\
\hline & & $\begin{array}{l}\text { És important que el ciutadà sàpia en què } \\
\text { s'inverteix el pressupost. }\end{array}$ & & \\
\hline & & Si se'n fa públiques, un 1. En cas contrari, un $O$. & & \\
\hline
\end{tabular}


MEI, II, Vol. 3, nº 5, pág. 229

\begin{tabular}{|c|c|c|c|c|}
\hline \multicolumn{3}{|c|}{ Contractes menors } & & \multirow{4}{*}{$\begin{array}{l}1 \\
1\end{array}$} \\
\hline \multirow[t]{3}{*}{3.05 . } & \multirow{3}{*}{$\begin{array}{l}\text { Publicitat de } \\
\text { contractes menors }\end{array}$} & Es fa públic el nombre de contractes menors? & \multirow[t]{3}{*}{ O } & \\
\hline & & $\begin{array}{l}\text { Com a mínim haurien de figurar de forma } \\
\text { resumida, amb el nombre total i l'import global. }\end{array}$ & & \\
\hline & & Si se'n fa públic, un 1. En cas contrari, un 0. & & \\
\hline \multicolumn{4}{|c|}{ Convenis de col-laboració, ajudes nominals i ajudes de concurrència pública } & 4 \\
\hline \multirow[t]{3}{*}{ 3.06. } & \multirow[t]{3}{*}{$\begin{array}{l}\text { Base de dades de } \\
\text { convenis de } \\
\text { col·laboració }\end{array}$} & $\begin{array}{l}\text { N'hi ha una base de dades en què es puguen } \\
\text { consultar els convenis de col·laboració subscrits } \\
\text { pels diferents departaments, tinguen o no } \\
\text { obligacions econòmiques? }\end{array}$ & \multirow[t]{3}{*}{ O } & \multirow[t]{3}{*}{1} \\
\hline & & $\begin{array}{l}\text { Els convenis de col·laboració són un instrument de } \\
\text { finançament que pot passar desapercebut. En el cas } \\
\text { de tindre obligacions econòmiques, cal que figure } \\
\text { l'import. }\end{array}$ & & \\
\hline & & $\begin{array}{l}\text { En el cas de tindre'n una pública, s'aplicarà un } 1 . \\
\text { En cas contrari, un } 0 .\end{array}$ & & \\
\hline \multirow[t]{3}{*}{ 3.07. } & \multirow[t]{3}{*}{$\begin{array}{l}\text { Base de dades } \\
\text { d'ajudes nominals }\end{array}$} & $\begin{array}{l}\text { N'hi ha una base de dades en què es puguen } \\
\text { consultar les ajudes nominals que reben les } \\
\text { entitats? }\end{array}$ & \multirow[t]{3}{*}{0} & \multirow[t]{3}{*}{1} \\
\hline & & $\begin{array}{l}\text { Les ajudes nominals apareixen normalment en la } \\
\text { llei de pressupostos. Caldria que es pogueren } \\
\text { consultar en una base de dades amb el nom de } \\
\text { l'entitat beneficiària, partida pressupostària i } \\
\text { l'import. }\end{array}$ & & \\
\hline & & $\begin{array}{l}\text { En el cas de tindre'n una pública, s'aplicarà un } 1 . \\
\text { En cas contrari, un } 0 .\end{array}$ & & \\
\hline \multirow[t]{3}{*}{3.08 . } & \multirow{3}{*}{$\begin{array}{l}\text { Base de dades } \\
\text { d'ajudes de } \\
\text { concurrència } \\
\text { pública }\end{array}$} & $\begin{array}{l}\text { N'hi ha una base de dades en què es puguen } \\
\text { consultar les ajudes de concurrència pública? }\end{array}$ & \multirow[t]{3}{*}{$\mathrm{O}$} & \multirow[t]{3}{*}{1} \\
\hline & & $\begin{array}{l}\text { Caldria que es pogueren consultar en una base de } \\
\text { dades amb el nom de l'entitat beneficiària, partida } \\
\text { pressupostària i l'import. }\end{array}$ & & \\
\hline & & $\begin{array}{l}\text { En el cas de tindre'n una pública, s'aplicarà un } 1 . \\
\text { En cas contrari, un } 0 .\end{array}$ & & \\
\hline \multirow[t]{3}{*}{3.09 . } & \multirow[t]{3}{*}{$\begin{array}{l}\text { Publicitat de } \\
\text { beneficiaris }\end{array}$} & $\begin{array}{l}\text { Es fan públiques llistes conjuntes de beneficiaris } \\
\text { que hagen rebut ajudes nominals o de concurrència } \\
\text { pública, a més de signar convenis amb obligacions } \\
\text { econòmiques? }\end{array}$ & \multirow[t]{3}{*}{$\mathrm{O}$} & \multirow[t]{3}{*}{1} \\
\hline & & $\begin{array}{l}\text { Un llistat conjunt de beneficiaris serveix per } \\
\text { comparar dades. }\end{array}$ & & \\
\hline & & $\begin{array}{l}\text { Si se'n fan públiques, s'aplicarà un } 1 \text {. En cas } \\
\text { contrari, un } 0 \text {. }\end{array}$ & & \\
\hline \multicolumn{3}{|c|}{ Relacions amb els proveïdors i contractistes } & & 1 \\
\hline \multirow{3}{*}{\multicolumn{2}{|c|}{$\begin{array}{l}\text { 3.10. } \\
\text { Publicitat de } \\
\text { despeses en } \\
\text { contractació i } \\
\text { compres }\end{array}$}} & $\begin{array}{l}\text { Es fan públiques en una llista les relacions de les } \\
\text { despeses en les contractacions i compres que } \\
\text { hagen de publicar-se en diferents diaris oficials? }\end{array}$ & \multirow[t]{3}{*}{ O } & \multirow[t]{3}{*}{1} \\
\hline & & $\begin{array}{l}\text { És important que figuren en una llista perquè } \\
\text { siguen fàcilment consultables. }\end{array}$ & & \\
\hline & & $\begin{array}{l}\text { Si se'n fan públiques, s'aplicarà un } 1 \text {. En cas } \\
\text { contrari, un } 0 .\end{array}$ & & \\
\hline
\end{tabular}


MEI, II, Vol. 3, n 5, pág. 230

\begin{tabular}{|c|c|c|c|c|}
\hline \multicolumn{3}{|c|}{ Contractacions per obra } & \multirow{4}{*}{$\mathrm{O}$} & \multirow{4}{*}{$\begin{array}{l}4 \\
1\end{array}$} \\
\hline \multirow[t]{3}{*}{3.11} & \multirow[t]{3}{*}{$\begin{array}{l}\text { Publicitat de les } \\
\text { contractacions d'obres } \\
\text { públiques }\end{array}$} & $\begin{array}{l}\text { Es fa una relació de les contractacions per } \\
\text { realitzar infraestructures públiques amb les } \\
\text { seues dades? }\end{array}$ & & \\
\hline & & $\begin{array}{l}\text { Cal que figuren les següents dades: l'objecte de } \\
\text { l'obra, el contractista responsable, import de } \\
\text { l'adjudicació, termini d'execució, data d'inici i } \\
\text { acabament. }\end{array}$ & & \\
\hline & & $\begin{array}{l}\text { Si se'n fan públiques, s'aplicarà un } 1 . \text { En cas } \\
\text { contrari, un } 0 .\end{array}$ & & \\
\hline \multirow[t]{3}{*}{3.12} & \multirow{3}{*}{$\begin{array}{l}\text { Publicitat de les } \\
\text { modificacions dels } \\
\text { projectes d'obra pública }\end{array}$} & $\begin{array}{l}\text { Es publiquen les modificacions dels projectes } \\
\text { d'obra més importants? }\end{array}$ & \multirow[t]{3}{*}{ O } & \multirow[t]{3}{*}{1} \\
\hline & & $\begin{array}{l}\text { Les modificacions dels projectes han de figurar } \\
\text { per saber quin és l'estat de la qüestió. Com a } \\
\text { mínim, ha de figurar allò que en supose un } \\
\text { desviament substancial de l'inicial. }\end{array}$ & & \\
\hline & & $\begin{array}{l}\text { Si se'n fan públiques, s'aplicarà un } 1 \text {. En cas } \\
\text { contrari, un } 0 .\end{array}$ & & \\
\hline \multirow[t]{3}{*}{3.13} & \multirow{3}{*}{$\begin{array}{l}\text { Publicitat de les } \\
\text { pròrrogues }\end{array}$} & Es fan públiques les pròrrogues? & \multirow[t]{3}{*}{$\mathrm{O}$} & \multirow[t]{3}{*}{1} \\
\hline & & $\begin{array}{l}\text { Les pròrrogues és una solució que permet la } \\
\text { legislació vigent en alguns casos. Ha de constar } \\
\text { el termini que té la pròrroga. }\end{array}$ & & \\
\hline & & $\begin{array}{l}\text { Si se'n fan públiques, s'aplicarà un } 1 . \text { En cas } \\
\text { contrari, un } 0 .\end{array}$ & & \\
\hline \multirow[t]{3}{*}{3.14} & \multirow[t]{3}{*}{$\begin{array}{l}\text { Publicitat de l'estat de } \\
\text { les obres públiques }\end{array}$} & $\begin{array}{l}\text { Es difon semestralment l'estat de les obres } \\
\text { d'infraestructura, informant sobre les que s'estan } \\
\text { executant i les que estan aprovades pendents } \\
\text { d'execució? }\end{array}$ & \multirow[t]{3}{*}{$\mathrm{O}$} & \multirow[t]{3}{*}{1} \\
\hline & & $\begin{array}{l}\text { L'existència d'un llistat actualitzat permet saber } \\
\text { l'estat de la qüestió. }\end{array}$ & & \\
\hline & & $\begin{array}{l}\text { Si se'n fa públic, s'aplicarà un } 1 \text {. En cas contrari, } \\
\text { un } 0 .\end{array}$ & & \\
\hline
\end{tabular}


MEI, II, Vol. 3, nº 5, pág. 231

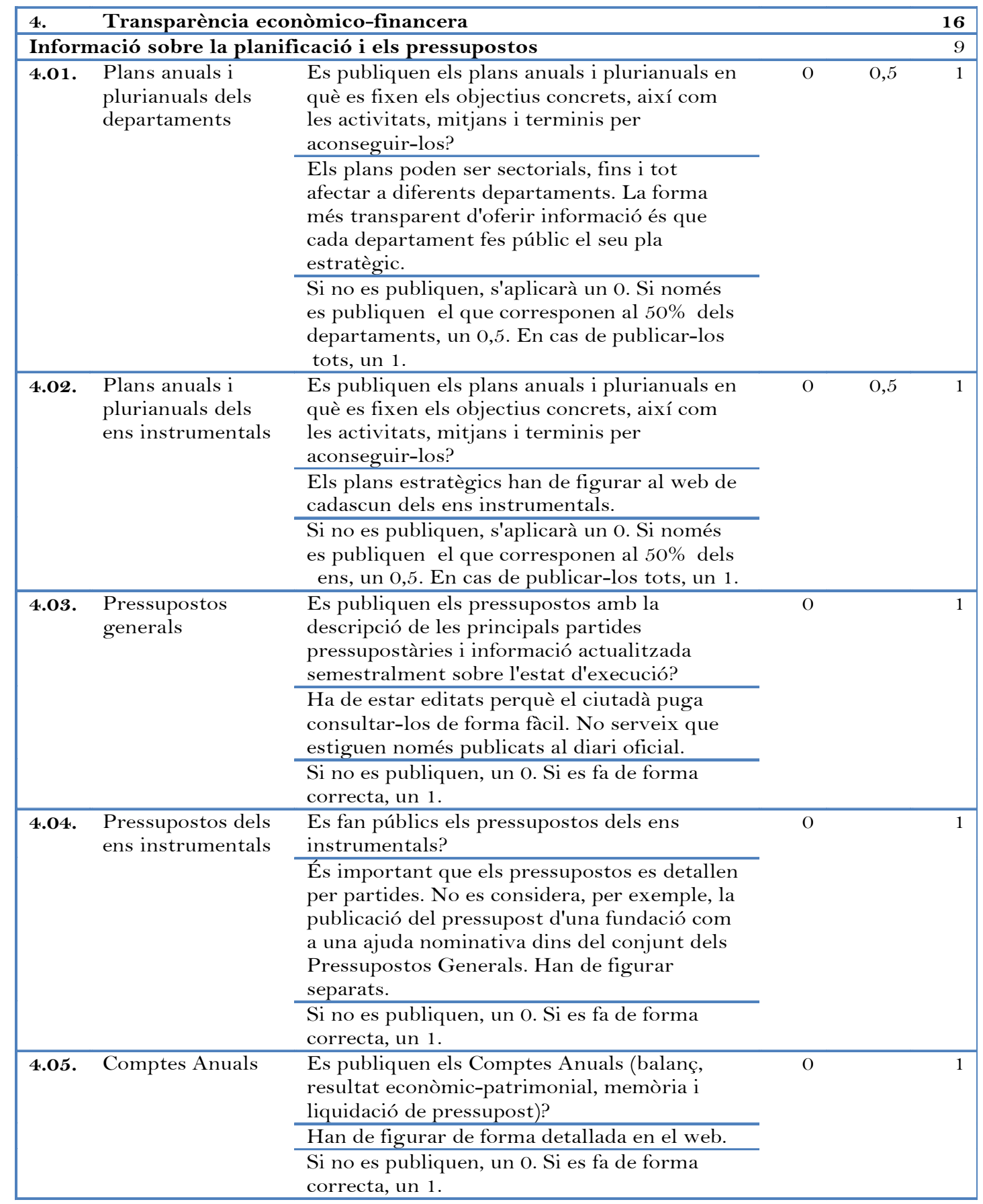


MEI, II, Vol. 3, n 5, pág. 232

\begin{tabular}{|c|c|c|c|c|}
\hline \multirow[t]{3}{*}{4.06.} & \multirow[t]{3}{*}{$\begin{array}{l}\text { Comptes dels ens } \\
\text { instrumentals }\end{array}$} & $\begin{array}{l}\text { Es fan públics els Comptes Anuals dels ens } \\
\text { instrumentals (balanç, resultat econòmic- } \\
\text { patrimonial, memòria i liquidació de pressupost)? }\end{array}$ & \multirow[t]{3}{*}{$\mathbf{0}$} & \multirow[t]{3}{*}{1} \\
\hline & & Han de figurar de forma detallada en el web. & & \\
\hline & & $\begin{array}{l}\text { Si no es publiquen, un } 0 . \text { Si es fa de forma correcta, } \\
\text { un } 1 .\end{array}$ & & \\
\hline \multirow[t]{3}{*}{4.07.} & \multirow[t]{3}{*}{$\begin{array}{l}\text { Publicitat de les } \\
\text { modificacions de } \\
\text { crèdit }\end{array}$} & $\begin{array}{l}\text { Es fan públics els crèdits extraordinaris, les } \\
\text { ampliacions i suplements de crèdits que afecten als } \\
\text { Pressupostos Generals? }\end{array}$ & \multirow[t]{3}{*}{0.} & \multirow[t]{3}{*}{1} \\
\hline & & $\begin{array}{l}\text { La publicitat és bàsica per saber en què es gasten } \\
\text { els pressupostos. }\end{array}$ & & \\
\hline & & Si es fan públiques, un 1. En cas contrari, un 0. & & \\
\hline \multirow[t]{3}{*}{4.08.} & \multirow{3}{*}{$\begin{array}{l}\text { Publicitat dels } \\
\text { informes } \\
\text { d'estabilitat } \\
\text { pressupostària }\end{array}$} & $\begin{array}{l}\text { Es publiquen els informes en què es detalla el } \\
\text { compliment dels objectius d'estabilitat } \\
\text { pressupostària? }\end{array}$ & \multirow[t]{3}{*}{0} & \multirow[t]{3}{*}{1} \\
\hline & & $\begin{array}{l}\text { S'han de fer d'acord amb el Sistema Europeu de } \\
\text { Comptes Nacionals i Regionals (SEC-95). } \\
\text { Reglamento (CE) núm. 2223/96 del Consejo, de } 25 \\
\text { de junio de 1996, relativo al Sistema Europeo de } \\
\text { Cuentas Nacionales y Regionales de la Comunidad. }\end{array}$ & & \\
\hline & & Si es fan públics, un 1. En cas contrari, un o. & & \\
\hline \multirow[t]{3}{*}{4.09.} & \multirow[t]{3}{*}{$\begin{array}{l}\text { Publicació del Pla } \\
\text { Econòmic-Financer }\end{array}$} & $\begin{array}{l}\text { Es fa públic el Pla Econòmic-Financer amb la seua } \\
\text { execució mensual? }\end{array}$ & \multirow[t]{3}{*}{0} & \multirow[t]{3}{*}{1} \\
\hline & & $\begin{array}{l}\text { Article } 21 \text { de la Llei Orgànica } 2 / 2012 \text {, de } 27 \\
\text { d'abril, d'Estabilitat Pressupostària i Sostenibilitat } \\
\text { Financera. }\end{array}$ & & \\
\hline & & Si es fa públics, un 1. En cas contrari, un 0. & & \\
\hline
\end{tabular}


MEI, II, Vol. 3, n 5, pág. 233

\begin{tabular}{|c|c|c|c|c|}
\hline \multicolumn{4}{|c|}{ Transparència d'ingressos i despeses } & 4 \\
\hline \multirow[t]{3}{*}{4.10.} & \multirow[t]{3}{*}{$\begin{array}{l}\text { Publicitats dels } \\
\text { recursos financers }\end{array}$} & $\begin{array}{l}\text { Es fan públics els recursos financers indicant la seua } \\
\text { procedència? }\end{array}$ & \multirow[t]{3}{*}{0} & \multirow[t]{3}{*}{1} \\
\hline & & $\begin{array}{l}\text { Article } 4 \text { de la Llei Orgànica 3/2009, de } 18 \text { de } \\
\text { desembre, de Modificació de la Llei Orgànica } \\
\text { 8/1980, de } 22 \text { de setembre, de Finançament de les } \\
\text { Comunitats Autònomes. }\end{array}$ & & \\
\hline & & Si es fan públics, un 1. En cas contrari, un o. & & \\
\hline \multirow[t]{3}{*}{4.11.} & \multirow{3}{*}{$\begin{array}{l}\text { Ingressos fiscals } \\
\text { per habitant }\end{array}$} & Es fa públic aquest indicador? & \multirow[t]{3}{*}{ O } & \multirow[t]{3}{*}{1} \\
\hline & & $\begin{array}{l}\text { S'obté amb la següent fórmula: Capítol I, II i III } \\
\text { d'Ingressos / núm. d'habitants. }\end{array}$ & & \\
\hline & & Si es fa públic, un 1. En cas contrari, un 0. & & \\
\hline \multirow[t]{3}{*}{4.12.} & \multirow{3}{*}{$\begin{array}{l}\text { Despesa per } \\
\text { habitant }\end{array}$} & Es fa públic aquest indicador? & \multirow[t]{3}{*}{ O } & \multirow[t]{3}{*}{1} \\
\hline & & $\begin{array}{l}\text { S'obté amb la següuent fórmula: obligacions no } \\
\text { financeres reconegudes netes / núm. d'habitants. }\end{array}$ & & \\
\hline & & Si es fa públic, un 1. En cas contrari, un 0. & & \\
\hline \multirow[t]{3}{*}{4.13.} & \multirow{3}{*}{$\begin{array}{l}\text { Inversió per } \\
\text { habitant }\end{array}$} & Es fa públic aquest indicador? & \multirow[t]{3}{*}{ O } & \multirow[t]{3}{*}{1} \\
\hline & & $\begin{array}{l}\text { S'obté amb la següent fórmula: obligacions } \\
\text { financeres reconegudes / núm. d'habitants. }\end{array}$ & & \\
\hline & & Si es fa públic, un 1. En cas contrari, un 0. & & \\
\hline \multicolumn{3}{|c|}{ Transparència dels deutes } & & 3 \\
\hline \multirow{3}{*}{\multicolumn{2}{|c|}{$\begin{array}{l}\text { 4.14. Publicitat de } \\
\text { l'import del Deute }\end{array}$}} & $\begin{array}{l}\text { Es fa públic l'import del Deute públic i la seua } \\
\text { evolució, comparant-lo amb els exercicis anteriors? }\end{array}$ & \multirow[t]{3}{*}{$\mathrm{O}$} & \multirow[t]{3}{*}{1} \\
\hline & & $\begin{array}{l}\text { La publicitat de l'evolució és una dada significativa } \\
\text { per saber si la gestió ha estat eficient. }\end{array}$ & & \\
\hline & & Si es fa públic, un 1. En cas contrari, un 0. & & \\
\hline \multirow[t]{3}{*}{4.15.} & \multirow{3}{*}{$\begin{array}{l}\text { Endeutament per } \\
\text { habitant }\end{array}$} & Es fa públic aquest indicador? & \multirow[t]{3}{*}{$\mathrm{O}$} & \multirow[t]{3}{*}{1} \\
\hline & & La fórmula és: passiu exigible / núm. d'habitants. & & \\
\hline & & Si es fa públic, un 1. En cas contrari, un 0. & & \\
\hline \multirow[t]{3}{*}{4.16.} & \multirow{3}{*}{$\begin{array}{l}\text { Endeutament } \\
\text { relatiu }\end{array}$} & Es fa públic aquest indicador? & \multirow[t]{3}{*}{$\mathrm{O}$} & \multirow[t]{3}{*}{1} \\
\hline & & $\begin{array}{l}\text { La fórmula és: Deute de la Comunitat / Pressupost } \\
\text { total de la Comunitat. }\end{array}$ & & \\
\hline & & Si es fa públic, un 1. En cas contrari, un o. & & \\
\hline
\end{tabular}


MEI, II, Vol. 3, nº 5, pág. 234

\section{ANNEX II: TAULA DE CORRESPONDÈNCIES AMB ELS INDICADORS DE LLUÍS CODINA}

\begin{tabular}{|c|c|c|}
\hline \multicolumn{2}{|c|}{$\begin{array}{c}\text { Correspondència amb els indicadors de } \\
\text { transparència }\end{array}$} & Observacions \\
\hline \multicolumn{3}{|c|}{ 1. Autoria: identificació i solvència de la font } \\
\hline \multirow[t]{2}{*}{$\begin{array}{l}\text { Identificació } \\
\text { d'autoria }\end{array}$} & $\begin{array}{l}\text { Ambit dels politics } \\
\text { 1.01. Dades biogràfiques } \\
\text { 1.05. Assessors }\end{array}$ & \multirow{2}{*}{$\begin{array}{l}\text { Els càrrecs són els responsables últims de la gestió de } \\
\text { l'administració. La identificació de l'autoria va de la mà de la } \\
\text { publicitat de directoris complets que servisquen per } \\
\text { determinar qualsevol tipus de responsabilitat. Els directoris de } \\
\text { personal dels departaments són indispensables. }\end{array}$} \\
\hline & $\begin{array}{l}\text { Ambit dels funcionaris } \\
\text { 2.01. Directori de } \\
\text { personal i departaments }\end{array}$ & \\
\hline $\begin{array}{l}\text { 1.2. Adequació } \\
\text { d'autoria }\end{array}$ & & $\begin{array}{l}\text { L'adequació es garanteix des del moment en que el portal } \\
\text { respon a les competències de l'administració. És un indicador } \\
\text { que replega tots els que tenen relació amb els continguts, } \\
\text { explicant-ne les funcions i facilitant-ne la gestió. }\end{array}$ \\
\hline \multirow[t]{2}{*}{$\begin{array}{l}1.3 . \\
\text { Comunicació }\end{array}$} & $\begin{array}{l}\text { Ambit dels polítics } \\
\text { 1.02. Comunicació amb } \\
\text { polítics } \\
\text { 1.08. Perfils en xarxes } \\
\text { socials }\end{array}$ & $\begin{array}{l}\text { La comunicació és essencial per a la transparència. No només } \\
\text { ha d'existir la bústia clàssica que permeta l'enviament d'una } \\
\text { consulta. N'hi ha dos àmbits diferenciats: el dels polítics i el } \\
\text { dels funcionaris. El primer abasta el poder executiu, amb tot el } \\
\text { personal que l'acompanya. }\end{array}$ \\
\hline & $\begin{array}{l}\text { Ámbit dels funcionaris } \\
\text { 2.01. Directori de } \\
\text { personal i departaments } \\
\text { 2.17 Bústia de correu } \\
\text { genèrica }\end{array}$ & $\begin{array}{l}\text { Els funcionaris duen a terme les polítiques marcades. Es } \\
\text { genera en tot cas una altra manera de relacionar-se amb el } \\
\text { ciutadà. }\end{array}$ \\
\hline
\end{tabular}




\begin{tabular}{|c|c|c|}
\hline \multicolumn{3}{|c|}{ 2. Qualitat i quantitat d'informació } \\
\hline $\begin{array}{l}\text { 2.1. Tema, públic i } \\
\text { objectius }\end{array}$ & $\begin{array}{l}\text { 1.09. Funcions dels } \\
\text { departaments } \\
\text { 1.12. Adequació de les } \\
\text { funcions als } \\
\text { departaments }\end{array}$ & $\begin{array}{l}\text { L'anàlisi del públic a què s'adreça un portal administratiu } \\
\text { és molt complexe, perquè pot involucrar webs i } \\
\text { aplicacions de molts tipus. Per exemple, cursets per } \\
\text { aprendre una llengua pensats per a immigrants o } \\
\text { tramitacions de beques. Els públics són molt diversos. No } \\
\text { obstant això, l'anàlisi s'ha de realitzar basant-se en les } \\
\text { competències assumides i el desplegament d'eines que hi } \\
\text { permetran al ciutadà escometre-les. }\end{array}$ \\
\hline $\begin{array}{l}\text { 2.2. Interés } \\
\text { intrínsec }\end{array}$ & & $\begin{array}{l}\text { L'interés intrínsec s'ha d'aplicar de forma diferent. La } \\
\text { trivialitat és conseqüència de no resseguir els principis } \\
\text { legals que menen els portals administratius. }\end{array}$ \\
\hline $\begin{array}{l}2.3 . \\
\text { Originalitat/oport } \\
\text { unitat }\end{array}$ & & $\begin{array}{l}\text { L'originalitat o l'oportunitat són elements que ací no es } \\
\text { poden avaluar ni mitjançant anàlisis de visibilitat. Els } \\
\text { portals administratius tenen un públic esclau. }\end{array}$ \\
\hline $\begin{array}{l}\text { 2.4. Política } \\
\text { editorial }\end{array}$ & & $\begin{array}{l}\text { És un indicador que no pot usar-se en els portals } \\
\text { administratius. En tot cas, caldria invertir la definició. La } \\
\text { política editorial seria bona o roín segons l'adequació a } \\
\text { tots els indicadors, sobretot els que estableix la legislació } \\
\text { vigent. El portal ha de garantir uns preceptes legals. Si no } \\
\text { ho fa, no aplica una política editorial. }\end{array}$ \\
\hline $\begin{array}{l}\text { 2.5. Quantitat } \\
\text { d'informació }\end{array}$ & & $\begin{array}{l}\text { És un indicador que suposa la suma de molts altres, } \\
\text { perquè depén d'un gran nombre d'indicadors que } \\
\text { assenyalen el contingut que ha de figurar. }\end{array}$ \\
\hline 2.6. Rigor & & $\begin{array}{l}\text { El rigor implica una informació completa i eficaç. Molts } \\
\text { indicadors fan referència a aquest problema. }\end{array}$ \\
\hline 2.7. Edició & & $\begin{array}{l}\text { Aquest indicador hauria de redefinir-se. Es tractaria de } \\
\text { veure si s'han pres mesures per redactar textos que } \\
\text { s'adeqüen als ciutadans. }\end{array}$ \\
\hline \multirow[t]{2}{*}{ 2.8. Actualització } & 2.08. Actualització & \multirow[b]{2}{*}{$\begin{array}{l}\text { L'actualització s'ha de mesurar des de dues perspectives: } \\
\text { a) la que afecta als continguts que usa el ciutadà } \\
\text { diàriament i b) la que fa referència a qüestions de } \\
\text { transparència, com ara totes les llistes que s'han } \\
\text { d'incloure. Aquesta doble estratègia complica l'elaboració } \\
\text { d'una possible correspondència amb els indicadors de } \\
\text { Lluís Codina. Serviria, a tall d'exemple, la llista que } \\
\text { s'ofereix. }\end{array}$} \\
\hline & $\begin{array}{l}\text { 1.04. Agenda d'activitats } \\
\text { 1.16. Publicitat de } \\
\text { l'Oferta Pública } \\
\text { d'Ocupació } \\
\text { 1.17. Publicitat dels } \\
\text { concursos de personal } \\
\text { 1.18. Comunicació de la } \\
\text { informació que afecta a } \\
\text { l'Oferta Pública } \\
\text { d'Ocupació } \\
\text {... }\end{array}$ & \\
\hline $\begin{array}{l}\text { 2.9. Recursos } \\
\text { multimèdia }\end{array}$ & & $\begin{array}{l}\text { Pel que fa als portals administratius, els recursos } \\
\text { multimèdia estan associats a xarxes socials. Moltes } \\
\text { vegades no tenen més importància que un recull de } \\
\text { notícies. No obstant això, s'usen de vegades per explicar } \\
\text { una activitat no política. En relació a la transparència no } \\
\text { cal afegir-los com a indicador. }\end{array}$ \\
\hline $\begin{array}{l}2.10 . \text { Recursos } \\
\text { interactius }\end{array}$ & $\begin{array}{l}\text { 2.13. Catàleg de serveis } \\
\text { 2.14. Tramitacions en } \\
\text { línia } \\
\text { 3.06. Base de dades de } \\
\text { convenis de col·laboració } \\
\text { 3.07. Base de dades } \\
\text { d'ajudes nominals } \\
\text { 3.08. Base de dades } \\
\text { d'ajudes de concurrència } \\
\text { pública }\end{array}$ & $\begin{array}{l}\text { És un indicador essencial per saber si un portal } \\
\text { administratiu compleix amb la normativa d'accés al } \\
\text { ciutadà. La legislació obliga a que les tramitacions es } \\
\text { puguen gestionar en línia. }\end{array}$ \\
\hline $\begin{array}{l}2.11 . \\
\text { Arxiu/hemeroteca }\end{array}$ & & $\begin{array}{l}\text { Els portals administratius no tenen per què tindre } \\
\text { publicacions periòdiques. Aquest indicador no és } \\
\text { rellevant. }\end{array}$ \\
\hline
\end{tabular}


MEI, II, Vol. 3, nº 5, pág. 236

\begin{tabular}{|c|c|c|}
\hline \multicolumn{3}{|c|}{ 3. Navegació i recuperació } \\
\hline $\begin{array}{l}\text { 3.1. Navegació } \\
\text { constant }\end{array}$ & & $\begin{array}{l}\text { El problema d'un portal administratiu és que recull informació de molts } \\
\text { departaments. Cadascun acostuma a organitzar un web i el ciutadà entra moltes } \\
\text { vegades pel web del departament. Normalment, s'usa un sistema d'etiquetes que } \\
\text { serveix per recórrer el portal. }\end{array}$ \\
\hline 3.2. Expressivitat & $\begin{array}{l}\text { 2.06. Perfils per } \\
\text { col·lectius } \\
\text { 2.07. Perfils per } \\
\text { matèries }\end{array}$ & $\begin{array}{l}\text { La gran quantitat d'informació que replega un portal administratiu només pot } \\
\text { reflectir-se mitjançant perfils genèrics d'usuaris i de matèries o funcions. La moda } \\
\text { de canviar les denominacions dels departaments es soluciona amb aquests perfils, } \\
\text { que serveixen per estructurar els continguts. }\end{array}$ \\
\hline 3.3. Identificació & 2.05. Etiquetes & Vegeu sistema d'etiquetes. \\
\hline $\begin{array}{l}\text { 3.4. Recorregut } \\
\text { seqüencial }\end{array}$ & $\begin{array}{l}\text { 1.11. Navegació per } \\
\text { criteri de } \\
\text { dependència } \\
\text { departamental }\end{array}$ & És essencial perquè un ciutadà no perda informació. \\
\hline $\begin{array}{l}\text { 3.5. Navegació } \\
\text { estructural }\end{array}$ & & $\begin{array}{l}\text { No és un criteri aplicable als portals administratius en general. El sistema } \\
\text { d'etiquetes pot solucionar això, però una excessiva navegació estructural pot } \\
\text { generar recorreguts laberíntics que facen perdre informació al ciutadà. }\end{array}$ \\
\hline 3.6. Orientació & 1.13. Orientació & $\begin{array}{l}\text { La complexitat dels portals administratius obliga a emprar eines d'orientació } \\
\text { perquè no es perda el ciutadà. }\end{array}$ \\
\hline 3.7. Jerarquització & $\begin{array}{l}\text { 1.09. Funcions dels } \\
\text { departaments } \\
\text { 1.10. Mapa web } \\
\text { 1.12. Adequació de } \\
\text { les funcions als } \\
\text { departaments }\end{array}$ & $\begin{array}{l}\text { La jerarquització és bàsica en un portal administratiu. Es basa en les funcions } \\
\text { departamentals i en les jerarquies. }\end{array}$ \\
\hline $\begin{array}{l}\text { 3.8. Navegació } \\
\text { local }\end{array}$ & $\begin{array}{l}\text { 1.12. Adequació de } \\
\text { les funcions als } \\
\text { departaments }\end{array}$ & $\begin{array}{l}\text { Cada departament ha de desglossar les seues funcions, indicant-ne els } \\
\text { procediments, tramitacions, etc. }\end{array}$ \\
\hline 3.9. Índexs & $\begin{array}{l}\text { 2.06. Perfils per } \\
\text { col·lectius } \\
\text { 2.07. Perfils per } \\
\text { matèries }\end{array}$ & $\begin{array}{l}\text { El més semblant als índexs en un portal administratiu són els perfils. És cert que } \\
\text { dins de cada departament caldria plantejar-se l'existència d'índexs segons les } \\
\text { matèries o l'accés a bases de dades, però aquest no és l'objectiu d'aquest treball. }\end{array}$ \\
\hline $\begin{array}{l}\text { 3.10. Navegació } \\
\text { semàntica }\end{array}$ & & Serviria per generar recorreguts laberíntics. \\
\hline $\begin{array}{l}\text { 3.11. Sistema } \\
\text { d'etiquetes }\end{array}$ & 2.05. Etiquetes & $\begin{array}{l}\text { Són indispensables per agrupar diferents opcions. A més a més, han de figurar } \\
\text { com a element que identifique en tot moment les pàgines que li corresponen. }\end{array}$ \\
\hline $\begin{array}{l}\text { 3.12. Recuperació } \\
\text { d'informació }\end{array}$ & 2.04. Cercador intern & $\begin{array}{l}\text { L'única forma de recuperar informació és mitjançant un cercador intern en què se } \\
\text { plantegen la recerca simple i l'avançada. }\end{array}$ \\
\hline $\begin{array}{l}\text { 3.13. Recerca } \\
\text { avançada }\end{array}$ & 2.04. Cercador intern & \\
\hline $\begin{array}{l}\text { 3.14. Llenguatge } \\
\text { documental }\end{array}$ & & Estaria implícit en la incorporació de metadades. \\
\hline
\end{tabular}


MEI, II, Vol. 3, nº 5, pág. 237

\begin{tabular}{|c|c|c|}
\hline \multicolumn{3}{|l|}{ 4. Ergonomia } \\
\hline 4.1. Facilitat & $\begin{array}{l}\text { 2.14. Tramitacions en } \\
\text { línia }\end{array}$ & $\begin{array}{l}\text { L'ergonomia i la usabilitat afecten sobretot a les } \\
\text { tramitacions en línia. El fet de no augmentar } \\
\text { significativament l'ús dels formularis implica que no s'han } \\
\text { dissenyat com cal. }\end{array}$ \\
\hline \multicolumn{3}{|l|}{ 4.2. Flexibilitat } \\
\hline 4.3. Claredat & $\begin{array}{l}\text { 2.12. Manual corporatiu } \\
\text { de disseny }\end{array}$ & $\begin{array}{l}\text { L'existència d'un manual corporatiu de disseny perquè } \\
\text { qualsevol departament en faça un de fàcil lectura és } \\
\text { essencial. }\end{array}$ \\
\hline 4.4. Legibilitat & $\begin{array}{l}\text { 2.12. Manual corporatiu } \\
\text { de disseny }\end{array}$ & \\
\hline \multicolumn{3}{|l|}{$\begin{array}{l}\text { 4.5. Recursos } \\
\text { multimèdia }\end{array}$} \\
\hline 4.6. Velocitat & & $\begin{array}{l}\text { És un indicador difícil d'avaluar en un portal administratiu. } \\
\text { El trànsit depén d'horaris molt diversos i de factors } \\
\text { múltiples. }\end{array}$ \\
\hline \multicolumn{3}{|l|}{ 5. Visibilitat } \\
\hline 5.1. Lluminositat & & $\begin{array}{l}\text { Tot i que la incorporació d'enllaços cap a altres webs pot } \\
\text { considerar-se important, no ho és en els portals } \\
\text { administratius. El seu objectiu és facilitar una informació } \\
\text { que només poden produir ells. }\end{array}$ \\
\hline \multicolumn{3}{|l|}{$\begin{array}{l}\text { 5.2. Context de } \\
\text { l'enllaç }\end{array}$} \\
\hline \multicolumn{3}{|l|}{ 5.3. Anticipació } \\
\hline \multicolumn{3}{|l|}{ 5.4. Oportunitat } \\
\hline \multicolumn{3}{|l|}{ 5.5. Qualitat } \\
\hline \multicolumn{3}{|l|}{ 5.6. Actualització } \\
\hline \multicolumn{3}{|l|}{ 5.7. Tractament } \\
\hline \multicolumn{3}{|l|}{ 6. Ubiqüitat } \\
\hline 6.1. Títol & 2.09. Metadades & S'ha inclòs com a part de l'indicador de metadades. \\
\hline $\begin{array}{l}6.2 . \\
\text { Transparència }\end{array}$ & $\begin{array}{l}\text { 1.09. Funcions dels } \\
\text { diferents departaments } \\
\text { 1.12. Adequació de les } \\
\text { funcions als } \\
\text { departaments }\end{array}$ & $\begin{array}{l}\text { Les funcions haurien de servir per evidenciar la } \\
\text { transparència del portal. }\end{array}$ \\
\hline $\begin{array}{l}6.3 . \\
\text { Metainformació }\end{array}$ & 2.09. Metadades & $\begin{array}{l}\text { En un mateix indicador s'ha inclòs la incorporació de } \\
\text { metadades i l'ús de l'esquema Dublin Core. És essencial per } \\
\text { recuperar com cal la informació. }\end{array}$ \\
\hline 6.4. Dublin Core & 2.09. Metadades & \\
\hline 6.5. Popularitat & & $\begin{array}{l}\text { És un indicador que no preocupa. Els usuaris de } \\
\text { l'administració són tots els ciutadans, i no tenen cap rival. }\end{array}$ \\
\hline
\end{tabular}


MEI, II, Vol. 3, n 5, pág. 238

\begin{tabular}{|c|c|c|}
\hline \multicolumn{3}{|l|}{ 7. Processos } \\
\hline 7.1. Visió d'estatus & 2.14. Tramitacions en línia & $\begin{array}{l}\text { El saber en quin moment del procés o procediment està un } \\
\text { usuari és essencial perquè siga efectiu un web. Pel que fa als } \\
\text { portals administratius, és essencial per avaluar les aplicacions } \\
\text { que gestionen tramitacions. }\end{array}$ \\
\hline $\begin{array}{l}\text { 7.2. Ús de } \\
\text { convencions }\end{array}$ & $\begin{array}{l}\text { 2.12. Manual corporatiu de } \\
\text { disseny }\end{array}$ & $\begin{array}{l}\text { L'ús d'un llenguatge i d'unes icones que siguen comunes } \\
\text { entrarien dins del Manual de disseny. }\end{array}$ \\
\hline 8. Errors & & $\begin{array}{l}\text { La gestió dels errors, amb els missatges, la possibilitat de refer } \\
\text { el procediment, etc., són indicadors que s'inclouen en les } \\
\text { tramitacions en línia. }\end{array}$ \\
\hline 8.1. Desfer accions & 2.14. Tramitacions en línia & \\
\hline $\begin{array}{l}\text { 8.2. Missatges } \\
\text { d'error }\end{array}$ & 2.14. Tramitacions en línia & \\
\hline 8.3. Conseqüències & 2.14. Tramitacions en línia & \\
\hline
\end{tabular}

